\title{
Phytoplankton growth allometry and size- dependent C:N stoichiometry revealed by a variable quota model
}

\author{
Zhi-Ping Mei ${ }^{1,3, *}$, Zoe V. Finkel ${ }^{2}$, Andrew J. Irwin ${ }^{1}$ \\ ${ }^{1}$ Department of Math \& Computer Science, Mount Allison University, Sackville, New Brunswick E4L 1E6, Canada \\ ${ }^{2}$ Environmental Science Program, Mount Allison University, Sackville, New Brunswick E4L 1A5, Canada \\ ${ }^{3}$ Present address: University of Maryland Center for Environmental Science, Horn Point Laboratory, \\ PO Box 775, Cambridge, Maryland 21613, USA
}

\begin{abstract}
Size scaling of phytoplankton growth rates and size-dependent carbon to nitrogen (C:N) stoichiometry determine phytoplankton size structure and coupling of carbon and nitrogen cycling of marine ecosystems. They are critical in predicting the growth of phytoplankton spanning a wide range of sizes and their consequences for the biological pump in marine ecosystem models. The size scaling of phytoplankton growth and size-dependent $\mathrm{C}: \mathrm{N}$ stoichiometry are modelled by embedding size-dependent light-harvesting, nutrient acquisition and storage into Droop's quota-dependent phytoplankton growth model. The size-scaling exponent of maximum growth rate of phytoplankton is -0.17 (which is higher than the universal size-scaling exponent of $-1 / 4$ predicted by the metabolic theory of ecology) under saturated light and $\mathrm{NO}_{3}$. The size-scaling exponent of growth rate $(\mu)$ decreases with increasing light under saturated $\mathrm{NO}_{3}$, and decreases with decreasing $\mathrm{NO}_{3}$ concentration under saturated light. The allometry of equilibrium cellular $\mathrm{C}$ and $\mathrm{N}$ quota varies with light and $\mathrm{NO}_{3}$ concentrations. Under saturated light and $\mathrm{NO}_{3}$ concentration, $\mathrm{C}: \mathrm{N}$ increases slightly with cell size. Under limiting light, but saturated $\mathrm{NO}_{3}, \mathrm{C}: \mathrm{N}$ is close to the Redfield ratio and is not size dependent. Under limiting $\mathrm{NO}_{3}$ but saturated light, $\mathrm{C}: \mathrm{N}$ is higher than the Redfield ratio and increases with cell size. We identified the uncertainty of the size-scaling exponent of $\mu$ associated with key parameters, for which more data need to be collected in the lab and field.
\end{abstract}

KEY WORDS: Phytoplankton growth · Size scaling $\cdot$ Community structure $\cdot \mathrm{C}: \mathrm{N} \cdot$ Transport network Quota Resale or republication not permitted without written consent of the publisher

\section{INTRODUCTION}

The size of most of the marine phytoplankton cells across various taxonomic groups ranges from $<1$ to $10^{7} \mu^{3}$. Many ecological and physiological characteristics of phytoplankton, such as light absorption (Agustí 1991, Finkel 2001, Fujiki \& Taguchi 2002), photosynthesis (Finkel \& Irwin 2000, Finkel et al. 2004), nutrient uptake (Pasciak \& Gavis 1974, Aksnes \& Egge 1991, Hein et al. 1995, Sunda \& Huntsman 1997, Litchman et al. 2007), sinking rate (Smayda 1970, Waite et al. 1997) and metabolic and growth rate (Banse 1976, 1982, Schlesinger et al. 1981, Blasco et al. 1982, Geider et al.
1986, Tang 1995, Tang \& Peters 1995), are related to cell size. Phytoplankton cell size also determines the size of their grazers, since zooplankton of different sizes graze on prey of certain preferred size ranges (Hansen et al. 1994, Weitz \& Levin 2006). Therefore, phytoplankton size structure will determine the productivity of the phytoplankton community, export of organic carbon to the ocean interior through sinking and transfer of carbon to higher trophic levels through the food web in the ocean (Legendre \& Le Fevre 1989, Chisholm 1992, Finkel 2007).

In a stratified oligotrophic ocean with a limited nutrient supply from below the surface mixed layer, phytoplank- 
ton biomass is dominated by picoplankton, while the biomass is dominated by large phytoplankton in eutrophic oceans such as coastal upwelling regions with high rates of nutrient supply (Chisholm 1992). On seasonal time scales, phytoplankton spring blooms dominated by large diatoms start when the water column is stable and light in the surface mixed layer becomes sufficient. After the spring phytoplankton bloom, phytoplankton biomass declines and most of the biomass consists of small phytoplankton; nutrients are depleted and the water column is stratified. Therefore, phytoplankton size structure across various marine ecosystems varies with the ocean physics, which set the nutrient supply and irradiance to which phytoplankton are exposed (Li 2002). Both fossil records (Finkel et al. 2005, 2007) and recent observations (Daufresne et al. 2009) indicate that the size of phytoplankton decreases with increased stratification due to warming. Future climate change is believed to affect phytoplankton size structure of marine ecosystems by changing the ocean physics (Finkel et al. 2010). Therefore, it is critical to develop models that predict the changes in phytoplankton size structure with changing oceanic conditions based on phytoplankton physiology determined by cell size.

The metabolic theory of ecology predicts that under optimal growth conditions the mass-specific metabolic rate of living organisms is limited by their resource transportation network which is scaled with mass with the size-scaling exponent of $-1 / 4$ (West et al. 1997, Brown et al. 2004). The size-scaling exponent of the maximum growth rate $\left(\mu_{\max }\right)$ of phytoplankton reported in the literature is not quite certain. The $\mu_{\max }$ of phytoplankton is reported to be weakly size dependent (Sommer 1989). There are also reports of sizedependent $\mu_{\max }$ with the size-scaling exponent of $\mu_{\max }$ being greater than $-1 / 4$ (Banse 1982, Blasco et al. 1982, Tang 1995). Data on $\mu_{\max }$ compliled by Schlesinger et al. (1981) show a lower size-scaling exponent of -0.32 . If picoplankton-sized cells are included, the largest $\mu_{\max }$ is found in intermediate-sized cells, rather than in smallest cells (Raven 1994). Under sub-optimal conditions, phytoplankton growth is limited by resource acquisition rather than by the transportation network, and consequently, the size-scaling exponent of the growth rate deviates from the $-1 / 4$ rule (Finkel et al. 2004). In the context of climate change, changes in marine physics may alter the growth conditions of phytoplankton, and thus the size-scaling exponent of their growth. Understanding the changes in the sizescaling exponent of phytoplankton growth in response to changes in marine physics would be useful in order to predict the changes in the size structure of the phytoplankton community in the future ocean.

Mei et al. (2009) modeled size scaling of phytoplankton growth based on size-dependent resource acquisi- tion, using a Monod growth model. It is predicted that the size-scaling exponent of the cell-specific growth rate $(\mu)$ decreases in response to light and nutrient limitation (Mei et al. 2009). The Monod growth model assumes the Redfield $\mathrm{C}$ to $\mathrm{N}$ ratio (C:N) of resource acquisition and that $\mu$ is only determined by an external limiting resource level, without considering the dynamic variation of the cellular nutrient quota. Its applicability is limited to balanced growth conditions (Grover 1991, Sunda et al. 2009). As a result, it predicts that the smallest cells always out-compete larger cells at equilibrium, as the growth rate is the highest for the smallest cells. Phytoplankton nutrient quotas, e.g. of carbon $\left(Q_{C}\right)$ and nitrogen $\left(Q_{N}\right)$, are known to vary with light or nutrient availability, and the assimilation of $\mathrm{C}$ and $\mathrm{N}$ are not always balanced (Goldman et al. 1979, Falkowski 2000, Sterner \& Elser 2002).

Phytoplankton growth is the result of 3 processes. First, cells obtain energy and nutrients through photosynthesis and nutrient uptake. Then, the nutrient obtained is stored in cells, resulting in an increased nutrient quota. Finally, cells divide and assimilated organic matter is transferred to new cells. This process can be quantitatively described by a quota-dependent growth model (Droop 1968, 1973) which describes the non-linear relationship between $\mu$ and the cell quota $(Q)$ of the limiting nutrient and allows the $Q$ to vary dynamically with assimilation and growth (Droop 1968, 1973, Flynn 2008). Unlike the Monod model, Droop's quota-dependent growth model predicts that large cells may not be out-competed by small cells in an environment with a pulsed nutrient supply (Grover 1989, 1991, Tozzi et al. 2004); small cells dominate in a nutrient-poor and stratified environment, and large cells may flourish in a nutrient-rich upwelling ocean (Irwin et al. 2006). Droop's quota-dependent growth model is expected to model the size scaling of phytoplankton growth more realistically than the Monod model. For example, Verdy et al. (2009) reveal that over the size range of 0.5 to $10^{6}{\mu \mathrm{m}^{3}}^{3}$, the highest $\mu_{\max }$ of phytoplankton is in cells of an intermediate size range instead of in the smallest cells, which is consistent with observations (Raven 1994, Bec et al. 2008). However, the above-mentioned variable cell quota models (Grover 1989, 1991, Tozzi et al. 2004, Irwin et al. 2006, Verdy et al. 2009) only consider limitation by a single nutrient, nitrogen or phosphorus, without considering light limitation.

The C:N stoichiometry of phytoplankton cells may vary with taxonomic groups of different evolutionary histories and with the growth environment (see Finkel et al. 2010 for a review). In the water column, the environmental gradient of light is opposite to that of nutrients; the former declines, and the latter increases with depth. Both carbon and nitrogen acquisition, subjected 
to different limitations at a given location, are size dependent. Consequently, phytoplankton C:N stoichiometry may be size dependent. The C:N stoichiometry of phytoplankton cells has important consequences for estimating the new production of $\mathrm{C}$ based on nutrient supply, the nutritional value of phytoplankton cells for their grazers (Jones et al. 2002, Jones \& Flynn 2005), and thus the food web structure, the remineralization of particles and the dissolved inorganic carbon to nutrient ratio in deep water. Future climate change may alter the size structure of phytoplankton communities in the surface ocean; however, there is a lack of understanding about how the C:N stoichiometry of phytoplankton is linked to cell size (Allen \& Gillooly 2009).

Therefore, the first objective of the present study is to investigate why the size-scaling exponent of $\mu_{\max }$ is frequently higher than the $-1 / 4$ predicted by the metabolic theory of ecology, and to investigate the causes of variation in the size-scaling exponent of $\mu$ with light and nutrient conditions under steady state, based on Droop's quota-dependent model of phytoplankton growth. The size-dependent nutrient storage capacity is an important trade-off between size-dependent nutrient uptake and growth. A high nutrient storage capacity is achieved by increasing the cell size, which decreases the affinity to nutrients (Grover 1991, Litchman et al. 2007, Litchman \& Klausmeier 2008). Combining the allometry of these physiological rates in a dynamic quota model will improve our ability to predict phytoplankton size structure under a range of light and nutrient conditions.

The second objective is to simulate the variation in both $Q_{C}$ and $Q_{N}$ with cell size with the quota-dependent phytoplankton growth model in order to understand how size-related photosynthesis and nutrient uptake may affect the C:N stoichiometry of phytoplankton under different light and nutrient conditions. This will provide insights into how changes in the ocean environment and phytoplankton size structure may affect the $\mathrm{C}$ and $\mathrm{N}$ cycles of marine ecosystems.

We will first model the size scaling of $\mu$ and C:N of phytoplankton using Droop's quota-dependent growth model based on the empirical allometry of light and nutrient acquisition rates (Shuter 1978, Aksnes \& Egge 1991, Finkel 2001, Finkel et al. 2004, Litchman et al. 2007) and those of the minimum and maximum quota (Shuter 1978, Thompson et al. 1991, Menden-Deuer \& Lessard 2000, Montagnes \& Franklin 2001). Those empirical allometries are only available for a limited number of phytoplankton species, with a large degree of uncertainty. Therefore, we explore how variation in the empirical allometry of minimum and maximum quotas affects the size-scaling exponents of $\mu$ and $C: N$ stoichiometry.

\section{THE MODEL}

Size scaling of phytoplankton growth and cell quota. The size-dependence of phytoplankton growth can be described as $\mu=a V^{b}$, where $V\left(\mu m^{3}\right)$ is cell volume, $a$ is a taxonomic-dependent intercept, and $b$ is the size-scaling exponent. The size-scaling exponent $b$ is obtained by modelling $\mu$ of phytoplankton cells ranging from 1 to $80 \mu \mathrm{m}$ in diameter, the size range that covers most of the phytoplankton groups in the ocean, at a range of light and nutrient levels.

The growth of phytoplankton involves acquisition of resources from the surrounding environment, conversion of light energy into energy stored in organic carbon, assimilation of nutrients into cell biomass, and division to make new cells. Therefore, $Q$ changes dynamically in the course of growth. In contrast to the Monod model, which describes growth rate of microorganisms as a function of external resource concentrations, growth of phytoplankton is better described as a function of the cell quota of the limiting nutrient (Droop 1968, 1973):

$$
\mu_{i}=\mu_{\infty}\left(1-\frac{Q_{\min , i}}{Q_{i}}\right)
$$

where $\mu_{i}\left(\mathrm{~d}^{-1}\right)$ is the cell growth rate limited by nutrient $i$ ( $i=\mathrm{C}$ or $\mathrm{N}$ ). Phytoplankton growth could be limited either by light, which drives photosynthesis, carbon fixation, and eventually variation in $Q_{C}$, or by nutrients, which drive changes in $Q_{N}$. In the former carbon quota, $Q_{\mathrm{C}}\left(\mathrm{mmol} \mathrm{C} \mathrm{cell}^{-1}\right)$ is the limiting internal nutrient of growth, and in the latter nitrogen quota, $Q_{N}$ (mmol $\mathrm{N} \mathrm{cell}^{-1}$ ) limits growth. The realized $\mu$ is modelled as the minimum of light-limited, $\mu_{\mathrm{C}}$, and nutrientlimited growth, $\mu_{N}$, or, $\mu=\min \left(\mu_{N}, \mu_{C}\right)$. The infinity growth rate, $\mu_{\infty}$ is the theoretical maximum growth rate when $Q$ is at infinity. $Q_{\min }\left(\mathrm{mmol} \mathrm{cell}^{-1}\right)$ is the minimum quota, below which growth stops (Droop 1973). It represents the nutrient content required for maintaining survival and essential cell functions, such as those used in membranes of various organelles and genetic materials (Shuter 1978).

The quota-dependent growth model suggests that $\mu$ increases asymptotically with the nutrient quota, towards $\mu_{\infty}$. This indicates that when the limiting nutrient quota reaches a certain level, the cell division is no longer limited by $Q$, but is ultimately limited by the intrinsic nature of the cell, presumably the resource transportation network, according to the metabolic theory of ecology (West et al. 1997, Brown et al. 2004). Therefore, we assume that the $\mu_{\infty}$ of each size-class of phytoplankton is determined by its resource transportation network.

The size-scaling exponent of $\mu_{\infty}$ can be prescribed as $-1 / 4$, following the size scaling of the resource trans- 
portation network (West et al. 1997, West \& Brown 2005). However, this exponent is mostly derived for higher plants and mammals, and no such theoretical deduction has been made for phytoplankton yet (but see Raven 1994, Raven \& Kubler 2002, Finkel et al. 2004). Therefore, we do not intend to prescribe an ad hoc size-scaling exponent of $-1 / 4$ for $\mu_{\infty}$, but rather derive it from Eq. (1) using empirical allometric relationships for $Q_{\max }$ and $Q_{\min }$. $\mu_{\infty}$ can be approached, but never reached, as $Q$ is always $<\infty, \mu_{\infty}$ and its size-scaling exponent in Eq. (1) can be found through a practical variable $\mu_{\max }\left(\mathrm{d}^{-1}\right)$, the realized maximum growth rate which is defined as the growth rate when $Q$ reaches its maximum, $Q_{\max }$ under saturated light and $\mathrm{NO}_{3}$, using Eq. (1):

$$
\mu_{\max }=\mu_{\infty}\left(1-\frac{Q_{\min }}{Q_{\max }}\right)
$$

which gives

$$
\mu_{\infty}=\frac{\mu_{\max } \cdot Q_{\max }}{Q_{\max }-Q_{\min }}
$$

We assume that the numerator of the right-hand side of Eq. (3) represents the maximum nutrient uptake rate of the cell in steady state (Goldman \& MacCarthy 1978), which can be scaled to cell volume with the exponent 2/3 (Aksnes \& Egge 1991, Litchman et al. 2007). When the size-scaling exponent of $Q_{\mathrm{N}}^{\max }$ is greater than $Q_{\mathrm{N}}^{\min }$ (Table 1), nutrient storage capacity, $Q_{\max }-Q_{\min }$ increases with cell size. $\mu_{\infty}$ is taken as the minimum of $\mu_{\infty}$ based on $Q_{\max }$ and $Q_{\min }$ of C or N.

Therefore, when the size-scaling exponents of $Q_{\max }$ and $Q_{\min }$ are known, the size-scaling exponent of $\mu$ is determined by the size-scaling exponent of $Q_{\mathrm{C}}$ (under light limitation), or $Q_{\mathrm{N}}$ (under nutrient limitation) at equilibrium at a given $\mathrm{NO}_{3}$ and light level (Eq. 1). We use empirical size-dependent photosynthetic carbon fixation $\left(P_{\mathrm{C}}, \mathrm{mmol} \mathrm{C}\right.$ cell $\left.^{-1} \mathrm{~s}^{-1}\right)$ (Morel \& Bricaud 1981, Finkel et al. 2004), inorganic nitrogen uptake $\left(\rho_{N}\right.$, mmol N cell ${ }^{-1} \mathrm{~s}^{-1}$ ) (Pasciak \& Gavis 1974, Aksnes \&
Egge 1991, Litchman et al. 2007), and nutrient storage capacity $\left(Q_{\mathrm{N}}^{\max }-Q_{\mathrm{N}}^{\min }\right)$ (Table 1$)$ to model the sizedependent $Q_{\mathrm{C}}$ and $Q_{\mathrm{N}}$ at equilibrium, and hence, the size-scaling exponent of $\mu$, at a range of light and nutrient conditions. The size-scaling exponents of $\mu_{\infty}, \mu_{\max }$ and $\mu$, are calculated as the least square linear regression slopes of the log-transformed growth rates vs. logtransformed cell volume.

Size scaling of $\boldsymbol{Q}_{\mathrm{C}}$ and $\boldsymbol{Q}_{\mathrm{N}}$ and size-dependent C:N at equilibrium. $Q_{\mathrm{C}}$ varies with the input of $\mathrm{C}$ through photosynthesis, $P_{\mathrm{C}}$ and loss of cellular $\mathrm{C}_{\text {, including }}$ output of $\mathrm{C}$ to new cells $\left(\mu \cdot Q_{\mathrm{C}}\right)$, and respiration associated with $\mathrm{N}$ assimilation at $2.33 \mathrm{~mol} \mathrm{C}$ per mol $\mathrm{N}$ assimilated (Raven 1984):

$$
\frac{\mathrm{d} Q_{\mathrm{C}}}{\mathrm{d} t}=P_{\mathrm{C}}-\mu \cdot Q_{\mathrm{C}}-\mu \cdot Q_{\mathrm{N}} \cdot 2.33
$$

where $t$ is time. If the term $\left(\mu \cdot Q_{N} \cdot 2.33\right)$ is ignored for simplicity, $Q_{\mathrm{C}}$ at equilibrium, $Q_{\mathrm{C}}^{*}$, can be expressed as:

$$
Q_{\mathrm{C}}^{*}=\frac{P_{\mathrm{C}}+\mu_{\infty} \cdot Q_{\mathrm{C}}^{\min }}{\mu_{\infty}}
$$

$Q_{\mathrm{C}}^{*}$ varies with $P_{\mathrm{C} \text {, as }} Q_{\mathrm{C}}^{\min }$ and $\mu_{\infty}$ are known constants. At extremely low light, $P_{\mathrm{C}}$ approaches 0 , then approaches $Q_{C}^{\min }$. Consequently, the size-scaling exponent of $Q_{\mathrm{C}}^{*}$ approaches that of $Q_{\mathrm{C}}^{\min }$ with decreasing light.

Similarly, $Q_{\mathrm{N}}$ increases due to nitrogen uptake $\left(\rho_{\mathrm{N}}\right)$ and decreases due to assimilation of $\mathrm{N}$ to new biomass:

$$
\frac{\mathrm{d} Q_{\mathrm{N}}}{\mathrm{d} t}=\rho_{\mathrm{N}}-\mu \cdot Q_{\mathrm{N}}
$$

$Q_{\mathrm{N}}$ at equilibrium, $Q_{\mathrm{N}}^{*}$, is obtained as:

$$
Q_{\mathrm{N}}^{*}=\frac{\rho_{\mathrm{N}}+\mu_{\infty} \cdot Q_{\mathrm{N}}^{\min }}{\mu_{\infty}}
$$

That is, $Q_{\mathrm{N}}$ varies with $\rho_{\mathrm{N}}$ as $Q_{\mathrm{N}}^{\min }$ and $\mu_{\infty}$ are known. Similar to $P_{\mathrm{C}}$ above, under extremely low nutrient, $\rho_{\mathrm{N}}$ approaches 0 , and $Q_{\mathrm{N}}^{*}$ equilibrates toward that of

\begin{tabular}{|c|c|c|c|c|c|}
\hline Variable & a & Symbol & Unit & $b$ & Source \\
\hline$\rho_{N}^{\prime}$ & $a_{\mu_{\max }} \cdot a_{Q_{\mathrm{N}}^{\max }}$ & $a \rho_{\mathrm{N}}^{\max }$ & mmol cell ${ }^{-1} \mathrm{~s}^{-1}$ & 0.67 & Aksnes \& Egge (1991) \\
\hline$k$ & 0.1 & $a_{k}$ & $\mathrm{mmol} \mathrm{N} \mathrm{m}^{-3}$ & 0.33 & Litchman et al. (2007) \\
\hline$Q_{\mathrm{N}}^{\min }$ & $1.5 \times 10^{-12}$ & $a Q_{\mathrm{N}}^{\min }$ & mmol $\mathrm{N}$ cell ${ }^{-1}$ & 0.72 & Shuter (1978) \\
\hline$Q_{\mathrm{N}}^{\max }$ & $3.0 \times 10^{-12}$ & $a Q_{\mathrm{N}}^{\max }$ & mmol $\mathrm{N} \mathrm{cell}^{-1}$ & 0.85 & Blasco et al. (1982) \\
\hline$Q_{\mathrm{C}}^{\min }$ & $9.9 \times 10^{-12}$ & $a Q_{C}^{\min }$ & $\mathrm{mmol} \mathrm{C} \mathrm{cell}{ }^{-1}$ & 0.72 & Assumed, see 'Sensitivity test' \\
\hline$Q_{\mathrm{C}}^{\max }$ & $1.98 \times 10^{-12}$ & $a Q_{\mathrm{C}}^{\max }$ & mmol C cell ${ }^{-1}$ & 0.85 & Blasco et al. (1982) \\
\hline$C_{i}$ & $4.29 \times 10^{-12}$ & $a_{\mathrm{C}_{i}}$ & mg chl cell ${ }^{-1}$ & 0.75 or 0.66 & Finkel et al. (2004) \\
\hline$P_{\max }^{\prime}$ & $a_{\mu_{\max }} \cdot a Q_{\mathrm{C}}^{\max }$ & $a_{P_{\max }}$ & $\mathrm{mmol} \mathrm{C} \mathrm{cell}{ }^{-1} \mathrm{~s}^{-1}$ & 0.75 & Brown et al. (2004) \\
\hline
\end{tabular}

Table 1. Size-scaling parameters of nutrient uptake and photosynthesis, and cellular $\mathrm{C}$, chlorophyll (chl) and $\mathrm{N}$ quota in the form $a \cdot V^{b} . a$ and $b$ : intercept and size-scaling exponent, respectively. $V$ : cell volume in $\mu^{3}{ }^{3} \rho_{\mathrm{N}}^{\prime}$ : maximum nitrogen uptake, when nitrogen uptake is not limited by $\mathrm{N}: \mathrm{C}_{i} k$ : half saturation constant; $Q_{\mathrm{N}}^{\min }$ and $Q_{\mathrm{C}}^{\min }$ : minimum quota of $\mathrm{N}$ or $\mathrm{C}$, respectively; $Q_{\mathrm{N}}^{\max }$ and $Q_{\mathrm{C}}^{\max }$ : maximum quota of $\mathrm{N}$ or $\mathrm{C}$, respectively $C_{i}$ : cellular chl content; $P_{\text {max }}^{\prime}$ : maximum photosynthesis when, photosynthesis is not limited by $\mathrm{N}: \mathrm{C}_{i} \mu_{\max }$ : maximum growth rate 
$Q_{\mathrm{N}}^{\min }$. Therefore, the size-scaling exponent of $Q_{\mathrm{N}}$ approaches that of $Q_{\mathrm{N}}^{\min }$ with decreasing $\mathrm{NO}_{3}$. Under saturated light and $\mathrm{NO}_{3}, Q_{\mathrm{C}}^{*}$ and $Q_{\mathrm{N}}^{*}$ will respectively reach $Q_{\mathrm{C}}^{\max }$ and $Q_{\mathrm{N}}^{\max }$.

The size-dependence of $\mathrm{C}: \mathrm{N}$ stoichiometry is obtained from the size-dependent $Q_{\mathrm{C}}$ and $Q_{\mathrm{N}}$ at equilibrium. The size-dependent $\mathrm{C}: \mathrm{N}$ stoichiometry is the result of size-dependent resource ( $\mathrm{C}$ and $\mathrm{N}$ ) acquisition, assimilation, storage capacity, and growth rates, and is affected by the availability of resources, such as light and nutrient.

Size-dependent photosynthetic carbon fixation $\left(P_{\mathrm{C}}\right)$ and nutrient uptake $\left(\rho_{\mathrm{N}}\right) . P_{\mathrm{C}}\left(\mathrm{mmol} \mathrm{C} \mathrm{cell}^{-1} \mathrm{~d}^{-1}\right)$ is a hyperbolic function of irradiance $\left(E, \mu \mathrm{mol}\right.$ photons $\mathrm{m}^{-2}$ $\left.\mathrm{s}^{-1}\right) . P_{\mathrm{C}}$ increases nonlinearly with $E$ until the maximum $P_{\mathrm{C}}\left(P_{\max }, \mathrm{mmol} \mathrm{C}\right.$ cell $\left.^{-1} \mathrm{~d}^{-1}\right)$ is reached at saturating light:

$$
P_{\mathrm{C}}=P_{\max }\left[1-\exp \left(\frac{-a \cdot \phi \cdot E}{P_{\max }}\right)\right]
$$

where $a\left(\mathrm{~m}^{2} \mathrm{cell}^{-1}\right)$ is the cell-specific light absorption coefficient. The size-scaling exponent of $P_{\mathrm{C}}$ is determined by that of $P_{\max }$, with the size-scaling exponent of $3 / 4$ under saturating light (Finkel et al. 2004) and by light absorption with the size-scaling exponent of $2 / 3$ under limiting light (Finkel et al. 2004). The $\phi$ reported in the literature ranges from 0.02 to $0.1 \mathrm{~mol} \mathrm{C}$ (mol photons) ${ }^{-1}$ depending on nutrient status and taxonomic groups (Falkowski \& Raven 2007). As our focus is on the sizescaling exponent of $P_{\mathrm{C}}$ and variation in $\phi$ does not affect the size-scaling exponent of $P_{\mathrm{C}}$ a constant $\phi$ of $0.03 \mathrm{~mol} \mathrm{C}$ (mol photons) ${ }^{-1}$ is assumed for simplicity, because this value has been observed in waters of a wide range of trophic status (Falkowski \& Raven 2007).

The cell-specific light absorption coefficient $(a)$ is computed following Finkel et al. (2004), taking into account the size-dependent package effects of photosynthetic pigment (chlorophyll, chl) (Morel \& Bricaud 1981). The package effect, which increases with cellular chl concentration and cell diameter, decreases the light absorption efficiency of photosynthetic pigments (Morel \& Bricaud 1981). The size-scaling exponent of cellular chl content $\left(C_{i}, \mathrm{mg}_{\mathrm{chl}} \mathrm{cell}^{-1}\right)$ varies from 0.75 when growing at saturated light to 0.66 at limiting light due to the trade-off between the benefits of light absorption and the cost of pigment synthesis (Finkel et al. 2004). However, for simplicity, the size-scaling exponent of $C_{i}$ is taken as 0.75 and 0.66 for saturated and limiting light, respectively (Table 1 ). $C_{i}$ also varies with irradiance due to photoacclimation, with chl decreasing exponentially with increasing $E$. Therefore, the intercept of the allometric relationship of $C_{i}$ is downregulated with increasing $E$, following Behrenfeld et al. (2002), who compiled light-dependent variation of $c_{i}$ based on a reasonably large dataset:

$$
C_{i}=a_{c_{i}} \cdot \exp \left(-3.96 \cdot 10^{-3} \cdot E\right) V^{b_{c_{i}}}
$$

where $a_{c_{i}}$ is the intercept, and $b_{c_{i}}$, the size-scaling exponent.

Nutrient uptake rate $\left(\rho_{N}\right)$ is formulated as a Monod equation describing the hyperbolic relationship between nitrate $\left(\mathrm{NO}_{3}\right.$, assumed to be the sole inorganic nitrogen source) and $\rho_{\mathrm{N}}$ :

$$
\rho_{\mathrm{N}}=\rho_{\mathrm{N}}^{\max } \frac{\mathrm{NO}_{3}}{k+\mathrm{NO}_{3}}
$$

where $k\left(\mathrm{mmol} \mathrm{NO}_{3} \mathrm{~m}^{-3}\right)$ is the half-saturation constant, and $\rho_{\mathrm{N}}^{\max }\left(\mathrm{mmol} \mathrm{N}\right.$ cell $\left.{ }^{-1} \mathrm{~s}^{-1}\right)$, is the maximum nutrient uptake rate. The Monod equation predicts that under saturating nutrients, $\rho_{\mathrm{N}}$ is determined by the maximum number of nutrient uptake sites on the cell surface, and $\rho_{\mathrm{N}}^{\max } \propto V^{2 / 3}$ (Aksnes \& Egge 1991, Litchman et al. 2007), and is determined by $k$ under limiting nutrient concentrations. $k$ is related to the thickness of the boundary layer surrounding the cell surface, which is approximately the same as the diameter of particles in the phytoplankton cell size range. Therefore, $k$ is scaled with cell volume with the exponent $1 / 3$ (Aksnes \& Egge 1991, Litchman et al. 2007) (Table 1). Accordingly, the size-scaling exponent of $\rho_{\mathrm{N}}$ ranges from $2 / 3$ to $1 / 3$, depending on whether phytoplankton cells are nutrient saturated or limited.

In order to maintain $Q$ between $Q_{\max }$ and $Q_{\min }, P_{\max }$ and $\rho_{\mathrm{N}}^{\max }$ are regulated with the term $f(Q)=\left(\frac{Q_{\max }-Q}{Q_{\max }-Q_{\min }}\right)^{n}$, where $n=0.1$ is a shape parameter, and decrease nonlinearly with increasing $Q_{\mathrm{C}}$ and $Q_{\mathrm{N}}$, respectively. In addition, $P_{\max }$ and $\rho_{\max }$ are also regulated by the feedback between $\mathrm{C}$ and $\mathrm{N}$ metabolisms. This feedback is established through the simplified $\mathrm{N}$ :C-dependent regulation terms for $P_{\max }$ and $\rho_{\mathrm{N}}^{\max }$ following Geider et al. (1998), based on the fact that photosynthesis requires N-rich enzymes and photosynthetic machinery, whereas nutrient uptake requires energy stored in organic carbon during photosynthesis. The $\mathrm{N}$ :C-dependent regulation term for $P_{\max }$ is $f(\mathrm{~N}: \mathrm{C})_{\mathrm{C}}=\frac{\mathrm{N}: \mathrm{C}-\mathrm{N}: \mathrm{C}_{\min }}{\mathrm{N}: \mathrm{C}_{\max }-\mathrm{N}: \mathrm{C}_{\min }}$, and that for $\rho_{\mathrm{N}}^{\max }$ is $f(\mathrm{~N}: \mathrm{C})_{\mathrm{N}}=\left(\frac{\mathrm{N}: \mathrm{C}_{\max }-\mathrm{N}: \mathrm{C}}{\mathrm{N}: \mathrm{C}_{\max }-\mathrm{N}: \mathrm{C}_{\min }}\right)^{n}$, where $\mathrm{N}: \mathrm{C}_{\min }(=0.034)$ and $\mathrm{N}: \mathrm{C}_{\max }(=0.17)$ are minimum and maximum $\mathrm{N}: \mathrm{C}$ ratios, respectively. That is,

$$
\begin{gathered}
P_{\text {max }}=P_{\text {max }}^{\prime} f(Q) \cdot f(\mathrm{~N}: \mathrm{C})_{\mathrm{C}} \\
\rho_{\mathrm{N}}^{\max }=\rho_{\mathrm{N}}^{\prime} f(Q) \cdot f(\mathrm{~N}: \mathrm{C})_{\mathrm{N}}
\end{gathered}
$$

where $P_{\max }^{\prime}$ and $\rho^{\prime}{ }_{\mathrm{N}}$ are respectively the $P_{\max }$ and $\rho_{\mathrm{N}}^{\max }$ when they are not limited by $\mathrm{N}: \mathrm{C}$, and $Q$ is significantly less than $Q_{\max }$. This treatment is essential to keep $Q$ in the boundary between $Q_{\max }$ and $Q_{\min }$, and within the boundary of $\mathrm{N}: \mathrm{C}_{\min }$ and $\mathrm{N}: \mathrm{C}_{\max }$, but does not affect the size-scaling exponent of $\mu$, as it serves to control the assimilation of the element in extra supply 
relative to the limiting element, and $\mu$ is determined by the quota of limiting element.

Sensitivity test. The theoretical value of size-scaling exponents of $\rho_{\mathrm{N}}^{\max }$, and $k$ are consistent with observations (Aksnes \& Egge 1991, Hein et al. 1995, Harrison et al. 1996, Finkel et al. 2004, Litchman et al. 2007). In contrast, there are significant uncertainties with $Q_{\mathrm{N}}^{\max }$, which varies from 0.83 to 1 in the literature (Thompson et al. 1991, Verity et al. 1992, Montagnes et al. 1994, Montagnes \& Franklin 2001), and $Q_{\mathrm{N}}^{\min }$. There are few data available for $Q_{\mathrm{N}}^{\min }$ (Shuter 1978, Litchman et al. 2007). We are not aware of any report on $Q_{C}^{\min }$ and its size scaling. We assume the size-scaling exponent of $Q_{\mathrm{C}}^{\min }$ is the same as that of $Q_{\mathrm{N}}^{\min }$, as the biochemical compositions of structural materials are expected to be relatively invariant across phytoplankton of various size classes (Allen \& Gillooly 2009). This is supported by the dataset of Shuter (1978), which shows that the size-scaling exponent of $Q_{\mathrm{N}}^{\min }$ is the same as that of $Q_{\mathrm{P}}^{\min }$, the minimum phosphorus quota. Sensitivity tests of the size-scaling exponents of $Q_{\min }$ and $Q_{\max }$ were conducted by changing the size-scaling exponents of maximum $Q_{\mathrm{C}}$ and $Q_{\mathrm{N}}$ or minimum $Q_{\mathrm{C}}$ and $Q_{\mathrm{N}}$ simultaneously to understand how the size-scaling exponent of $\mu$ is affected by those uncertainties. We also looked at the effects of the proportion of $Q_{\min }$ relative to $Q_{\max }$ on the size-dependence of $\mu$.

Batch culture simulation. In the above simulations, we did not examine the dynamic responses of phytoplankton growth to changing resource availability, for the convenience of obtaining steady-state solutions. However, we did conduct 2 batch culture simulations, in which light was attenuated by phytoplankton biomass and $\mathrm{NO}_{3}$ depleted with phytoplankton growth, to show the transition of size-dependent growth in response to the dynamic variation of light and $\mathrm{NO}_{3}$. The 2 batch culture simulations differed in photosynthetically active radiation at the surface of the incubator (= $\mathrm{PAR}_{0}$ ) and the initial condition of $\mathrm{NO}_{3}$. In the first batch culture simulation, $\mathrm{PAR}_{0}$ was $100 \mu \mathrm{mol}$ photons $\mathrm{m}^{-2} \mathrm{~s}^{-1}$, and initial $\mathrm{NO}_{3}$ was $100 \mathrm{mmol} \mathrm{m}^{-3}$. The culture moved from saturated light and $\mathrm{NO}_{3}$ to saturated $\mathrm{NO}_{3}$, but with limiting light. In the second batch culture simulation, $\mathrm{PAR}_{0}$ was $500 \mu \mathrm{mol}$ photons $\mathrm{m}^{-2} \mathrm{~s}^{-1}$ and initial $\mathrm{NO}_{3}$ $10 \mathrm{mmol} \mathrm{m}^{-3}$, so that the culture moved from saturated light and $\mathrm{NO}_{3}$ to saturated light but limiting $\mathrm{NO}_{3}$. Biomass-specific light attenuation $\left(k_{\mathrm{N}}\right)$ was set to $0.10 \mathrm{~m}^{-1}$ $(\mathrm{mmol} \mathrm{N})^{-1}$, including attenuation by media, assuming the light was measured at $1 \mathrm{~m}$ depth of the culture.

The dynamics of cell abundances is:

$$
\frac{\mathrm{d} \mathrm{cell}_{i}}{\mathrm{~d} t}=\mu-m
$$

where $m$ is mortality of $0.1 \mathrm{~d}^{-1}$, and cell $l_{i}$ is the cell abundance of each size class. Then, the dynamics of $\mathrm{NO}_{3}$ is:

$$
\frac{\mathrm{dNO}_{3}}{\mathrm{~d} t}=-\sum_{i=1}^{n} \rho_{\mathrm{N}_{i}} \cdot \operatorname{cell}_{i}+\sum_{i=1}^{n} m \cdot \operatorname{cell}_{i} \cdot Q_{\mathrm{N}_{i}}
$$

Total nitrogen biomass at time $t, \mathrm{~N}(t)$, is the product of cell abundance, cell $(t)$ and $Q_{\mathrm{N}}$ at time $t, Q_{\mathrm{N}}(t)$ :

$$
\mathrm{N}(t)=\sum_{i=1}^{n} Q_{\mathrm{N}_{i}}(t) \cdot \operatorname{cell}_{i}(t)
$$

Finally, the light (PAR) in the culture is:

$$
\operatorname{PAR}(t)=\mathrm{PAR}_{0} \cdot \exp \left[-\mathrm{N}(t) \cdot k_{\mathrm{N}}\right]
$$

\section{RESULTS}

Phytoplankton experience light and $\mathrm{NO}_{3}$ levels that vary dynamically in the ocean. Their growth can be limited by light or $\mathrm{NO}_{3}$. We examined the size scaling of phytoplankton growth and C:N stoichiometry at saturated and limiting light and $\mathrm{NO}_{3}$ conditions.

\section{Size-scaling exponents of $\mu_{\infty}$ and $\mu_{\max }$}

Variations in size-dependent $Q_{\mathrm{C}}, Q_{\mathrm{N}}, \mu$ and C:N ratio with light ranging from saturation to limitation at saturated $\mathrm{NO}_{3}$ are shown in Fig. 1. With the standard parameters defined in Table 1, the size-scaling exponent of $\mu_{\infty}$ is -0.24 . We define $\mu_{\max }$ as $\mu$ at saturated light and $\mathrm{NO}_{3}$, when $Q_{\mathrm{C}}$ and $Q_{\mathrm{N}}$ reach their maximum (Fig 1a,b) (Eq. 2). At saturated light and $\mathrm{NO}_{3}, Q_{\mathrm{C}}$ and $Q_{\mathrm{N}}$ reach their maximum, as defined by the literature (Blasco et al. 1982, Menden-Deuer \& Lessard 2000). Therefore, $\mu$ for all the size classes at an irradiance of $320 \mu \mathrm{mol}$ photons $\mathrm{m}^{-2} \mathrm{~s}^{-1}$ and $\mathrm{NO}_{3}$ concentration of $100 \mathrm{mmol} \mathrm{m}^{-3}$ are taken as $\mu_{\max }$ (Fig. 1c). The size-scaling exponent of $\mu_{\max }$ of phytoplankton is -0.17 (Fig. 2).

The size-scaling exponent of $\mu_{\max }$ is higher than that of $\mu_{\infty i}$ that is, $\mu_{\max }$ is less size dependent than $\mu_{\infty} \mu_{\max }$ is close to $\mu_{\infty}$ for the largest cell studied, and the difference between $\mu_{\infty}$ and $\mu_{\max }$ increases with decreasing size (Fig. 1d). According to Eq. (2), the distance between $\mu_{\max }$ and $\mu_{\infty}$ is determined by the difference between $Q_{\min }$ and $Q_{\max }$. When the difference between $Q_{\min }$ and $Q_{\max }$ is small, the difference between $\mu_{\infty}$ and $\mu_{\max }$ is large. As the size-scaling exponent of $Q_{\max }$ is larger than that of $Q_{\min }$, the difference between $Q_{\min }$ and $Q_{\max }$ increases with cell size. Therefore, the difference between $\mu_{\infty}$ and $\mu_{\max }$ decreases with increasing cell size.

\section{Size-scaling exponent of $\mu$ and C:N stoichiometry under limiting light}

According to Eq. (1), $\mu$ is limited by either $Q_{\mathrm{C}}$ or $Q_{\mathrm{N}}$ whichever is closer to $Q_{\min }$. Under limiting light, $Q_{\mathrm{C}}$ is 


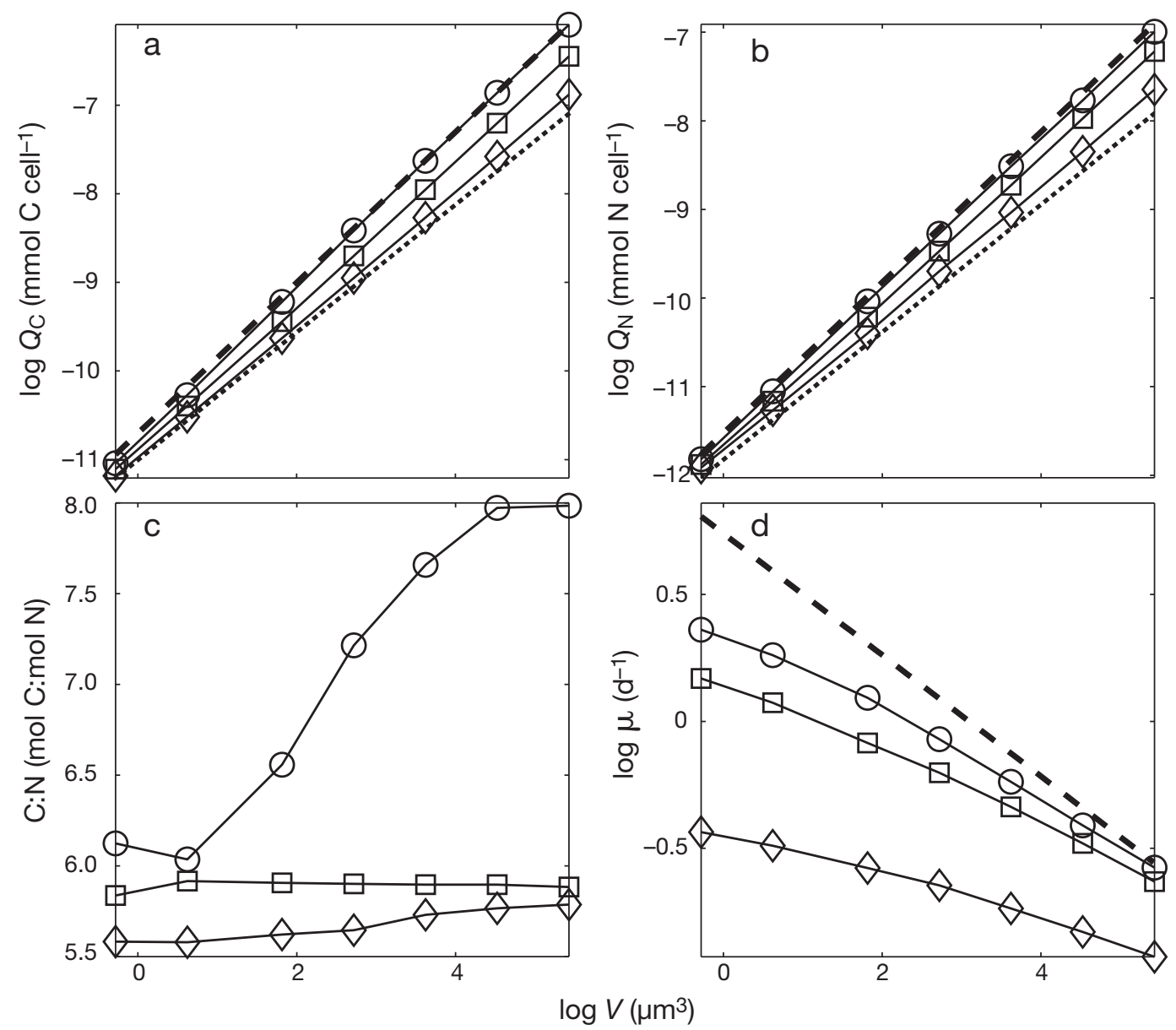

Fig. 1. Size-dependences of (a) the carbon quota $\left(Q_{C}\right)$, (b) the nitrogen quota $\left(Q_{N}\right),(\mathrm{c}) \mathrm{C}: \mathrm{N}$, and (d) the growth rate $(\mu)$, under saturated light of $320 \mu \mathrm{mol}$ photons $\mathrm{m}^{-2} \mathrm{~s}^{-1}(\mathrm{O})$, limited light of $32 \mu \mathrm{mol}$ photons $\mathrm{m}^{-2} \mathrm{~s}^{-1}(\square)$, and $5 \mu \mathrm{mol} \mathrm{photons} \mathrm{m}^{-2} \mathrm{~s}^{-1}(\diamond)$. NO concentration is $100 \mu \mathrm{mol} \mathrm{m}{ }^{-3}$. Bold long-dashed lines on (a), (b) and (d) are the maximum carbon quota $\left(Q_{\mathrm{C}}^{\max }\right)$, the maximum nitrogen quota $\left(Q_{\mathrm{N}}^{\max }\right)$ (Table 1, Montagnes \& Franklin 2001) and the infinity growth rate $\left(\mu_{\infty}\right)$, respectively. Short-dashed lines on (a) and (b) are the minimum carbon $\left(Q_{\mathrm{C}}^{\min }\right)$ and nitrogen quota $\left(Q_{\mathrm{N}}^{\min }\right)$ (Table 1$)$, respectively. $V$ : cell volume

closer to $Q_{\mathrm{C}}^{\min }$ than $Q_{\mathrm{N}}$ to $Q_{\mathrm{N}}^{\min }$ in all size-classes (Fig. 1a,b). With decreasing light, $Q_{\mathrm{C}}$ decreases towards $Q_{\mathrm{C}}^{\mathrm{min}}$ as predicted by Eq. (5), while $Q_{\mathrm{N}}$ slightly decreases. This slight decrease in $Q_{\mathrm{N}}$ is caused by a reduced nutrient uptake resulting from limitation by $Q_{\mathrm{C}}$ as $\rho_{\mathrm{N}}^{\max }$ is regulated by the $\mathrm{N}$ : C ratio (Eq. 12).

When $\mu$ is limited by light, $\mu=P_{C} / Q_{C}$ in steady state. The size-scaling exponent of $\mu$ is the difference between the size-scaling exponents of $P_{\mathrm{C}}$ and equilibrium $Q_{C}$. When light decreases from 320 to $5 \mu$ mol photons $\mathrm{m}^{-2} \mathrm{~s}^{-1}$, the size-scaling exponent of $P_{\mathrm{C}}$ slightly decreases from 0.72 to 0.67 (Fig. 2a) due to changes in the size-scaling exponent of $C_{i}$ and associated pigment package effects (Finkel \& Irwin 2000, Finkel et al. 2004, Mei et al. 2009), while the size-scaling exponent of $Q_{C}$ decreases from 0.87 to 0.77 (Fig. 2a), with $Q_{C}$ of smaller cells closer to $Q_{\mathrm{C}}^{\min }$ than larger cells (Fig. 1a). This gives rise to an increased size-scaling exponent of $\mu$ with decreasing light (Fig. 2a). That is, $\mu$ is less size dependent in limiting light than in saturating light (Fig. 1d).

The C:N stoichiometry of phytoplankton cells is the ratio between equilibrium $Q_{\mathrm{C}}$ and $Q_{\mathrm{N}}$ at different light levels. Under saturated light and $\mathrm{NO}_{3}$, the size-scaling exponent of equilibrium $Q_{C}$ is slightly higher than $Q_{\mathrm{N}}$, leading to a slightly increased $C: N$ with cell size. Under limiting light, $Q_{C}$ decreases more than $Q_{N}$, and the size-scaling exponent of equilibrium $Q_{C}$ is the same or slightly lower than that of $Q_{\mathrm{N}}$. Therefore, C:N is less size dependent under limiting light than under saturating light (Fig. 1c \& Table 1).

\section{Size-scaling exponent of $\mu$ and C:N stoichiometry under limiting $\mathrm{NO}_{3}$}

Under saturating light, when $\mathrm{NO}_{3}$ decreases from saturation $\left(50 \mathrm{mmol} \mathrm{m}^{-3}\right)$ to limiting $\left(0.05 \mathrm{mmol} \mathrm{m}^{-3}\right)$, 


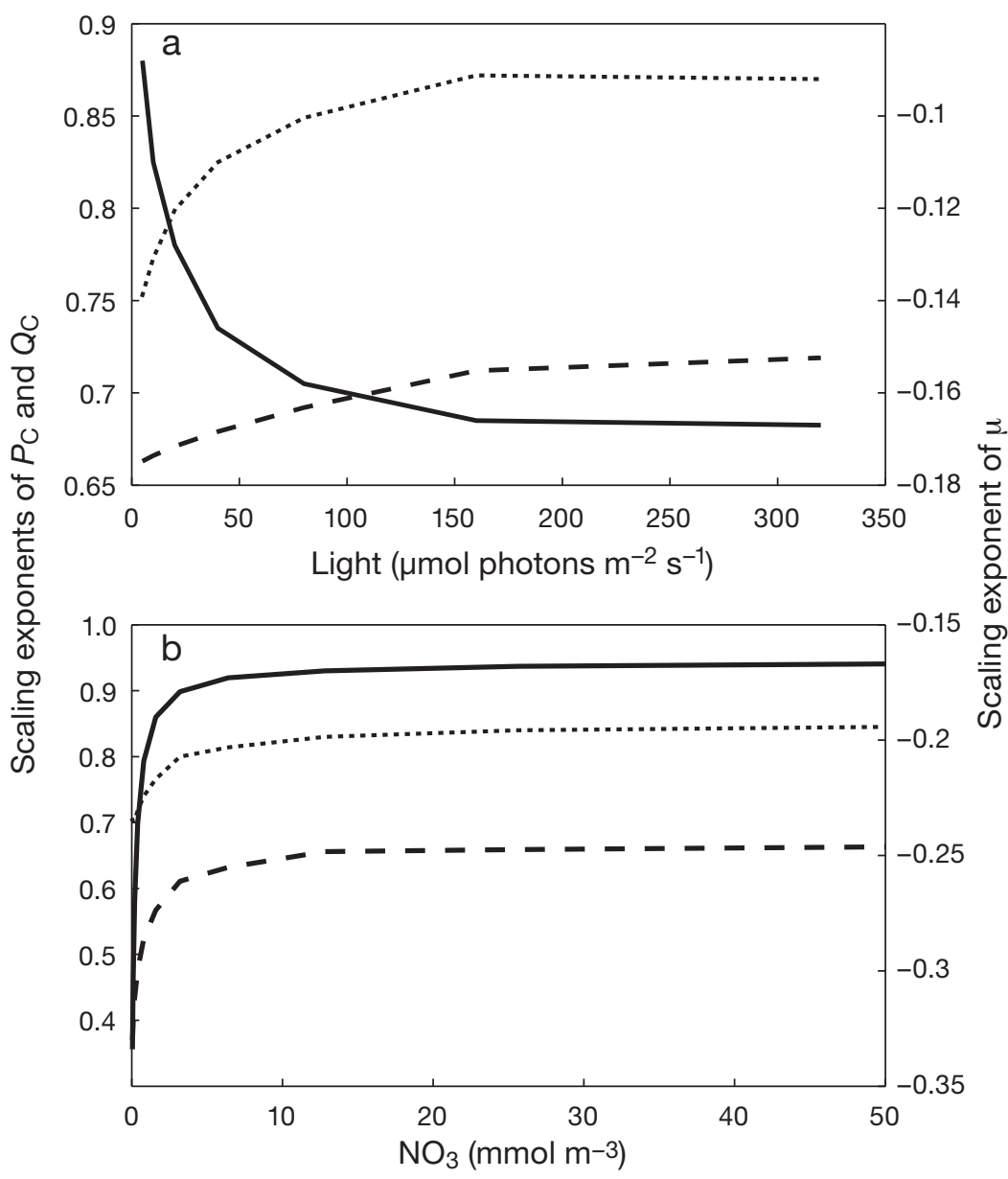

Fig. 2. (a) Effects of light on the size-scaling exponents of the carbon quota $\left(Q_{C}\right.$ short-dashed line), photosynthesis $\left(P_{\mathrm{C}}\right.$ long-dashed line) and growth rate $(\mu$, solid line) under constant $\mathrm{NO}_{3}$ of $100 \mathrm{mmol} \mathrm{m}{ }^{-3}$. (b) Effects of $\mathrm{NO}_{3}$ on the sizescaling exponents of the nitrogen quota $\left(Q_{N}\right.$, long-dashed line), nitrogen uptake $\left(\rho_{N}\right.$, short-dashed line) and growth (solid line) under constant light of $320 \mu \mathrm{mol}$ photons $\mathrm{m}^{-2} \mathrm{~s}^{-1}$

$Q_{\mathrm{N}}$ decreases towards $Q_{\mathrm{N}}^{\min }$, as predicted by Eq. (7) (Fig. 3b). $Q_{C}$ decreases slightly with $\mathrm{NO}_{3}$ (Fig. 3a) due to $P_{\mathrm{C}}$ being limited by $Q_{\mathrm{N}}$ (Eq. 11) (Fig. 3a). This results in an increased $\mathrm{C}: \mathrm{N}$ ratio with decreasing $\mathrm{NO}_{3}$ for each size-class, and an increased C:N with cell size (Fig. 3c), since the size-scaling exponent of $Q_{C}$ is greater than $Q_{\mathrm{N}}$ at equilibrium (Fig. 3a,b).

Under $\mathrm{NO}_{3}$ limitation, $\mu$ is limited by $Q_{\mathrm{N}}$, and hence $\mu=\rho_{N} / Q_{N}$ in steady state. Therefore, the size-scaling exponent of $\mu$ is the difference between the size-scaling exponents of $\rho_{\mathrm{N}}$ and equilibrium $Q_{\mathrm{N}}$. Under limiting nutrient, $\rho_{\mathrm{N}}$ is limited by diffusion of nutrients from media to cell surface (Eq. 10), and the size-scaling exponent of $\rho_{\mathrm{N}}$ decreases to 0.37 , while the size-scaling exponent of $Q_{\mathrm{N}}$ at equilibrium approaches that of $Q_{\mathrm{N}}^{\min }$. Therefore, the size-scaling exponent of $\mu$ decreases from -0.17 under saturating light and nutrient, to -0.34 under saturating light but limiting nutrient. That is, $\mu$ of larger cells decreases more than smaller cells in response to decreasing $\mathrm{NO}_{3}$ (Figs. 2b \& 3d). This is in contrast to light limitation, where the size-scaling exponent of $\mu$ increases with decreasing light (see 'Size-scaling exponent of $\mu$ and $C: N$ stoichiometry under limiting light').

\section{Sensitivity of the size-scaling exponent of $\mu$ to $Q_{\min }$ and $Q_{\max }$}

According to Eqs. (1) and (3), the sizescaling exponents of $Q_{\max }$ and $Q_{\min }$ affect the size-scaling exponent of $\mu$. So far, we have used empirical sizescaling relationships for $Q_{\min }$ and $Q_{\max }$ from the literature (Table 1) to predict the size-scaling exponent of $\mu$. The proportion of $Q_{\min }$ in $Q_{\max }$ and the sizescaling exponents of $Q_{\min }$ and $Q_{\max }$ vary with taxonomic groups. Therefore, we investigated the sensitivity of the sizescaling exponent of $\mu$ to the variations in the proportion of $Q_{\min }$ in $Q_{\max }$ and the size-scaling exponents of $Q_{\min }$ and $Q_{\max }$.

The sensitivity of size-dependent $\mu$ to variations in $Q_{\mathrm{C}}^{\mathrm{min}}$ and $Q_{\mathrm{N}}^{\min }$ were tested under saturating light and $\mathrm{NO}_{3} . Q_{\mathrm{C}}^{\min }$ is increased by changing the C:N ratio of $Q_{\min }$, with $Q_{\mathrm{N}}^{\min }$ being fixed, based on observations that some taxonomic groups of phytoplankton are more carbon-rich than others (e.g. MendenDeuer \& Lessard 2000, Montagnes \& Franklin 2001). By increasing the C:N ratio of $Q_{\min }$, more carbon is needed for cell survival and integrity of cell function at a given $Q_{\mathrm{N}}^{\min }$, and less carbon is available for synthesizing new biomass. Increasing $Q_{\mathrm{C}}^{\min }$ reduces the $\mu_{\max }$ of all size-classes, but the $\mu_{\max }$ of smaller cells $(1$ to $5 \mu \mathrm{m}$ ) is reduced more than that of larger cells (Fig. 4a). Increasing the $Q_{\mathrm{C}}^{\min }$ reduces a greater proportion of the nutrient storage capacity of smaller cells than that of larger cells, and thus, a greater proportion of the $\mu_{\max }$ of smaller cells is reduced than of larger cells. Similarly, when $Q_{\mathrm{C}}^{\min }$ is fixed, the $\mu$ of smaller cells decreases with increasing $Q_{\mathrm{N}}^{\min }$ (Fig. 4b).

The sensitivity test for the size-scaling exponent of $Q_{\text {min }}$ is conducted under limiting light (10 $\mu \mathrm{mol}$ photons $\mathrm{m}^{-2} \mathrm{~s}^{-1}$ ) but saturating $\mathrm{NO}_{3}$. The size-scaling exponent of both $Q_{\mathrm{C}}^{\min }$ and $Q_{\mathrm{N}}^{\min }$ are changed simultaneously, assuming that the $\mathrm{C}: \mathrm{N}$ ratio of structural materials is not size dependent. Increasing the size-scaling expo- 

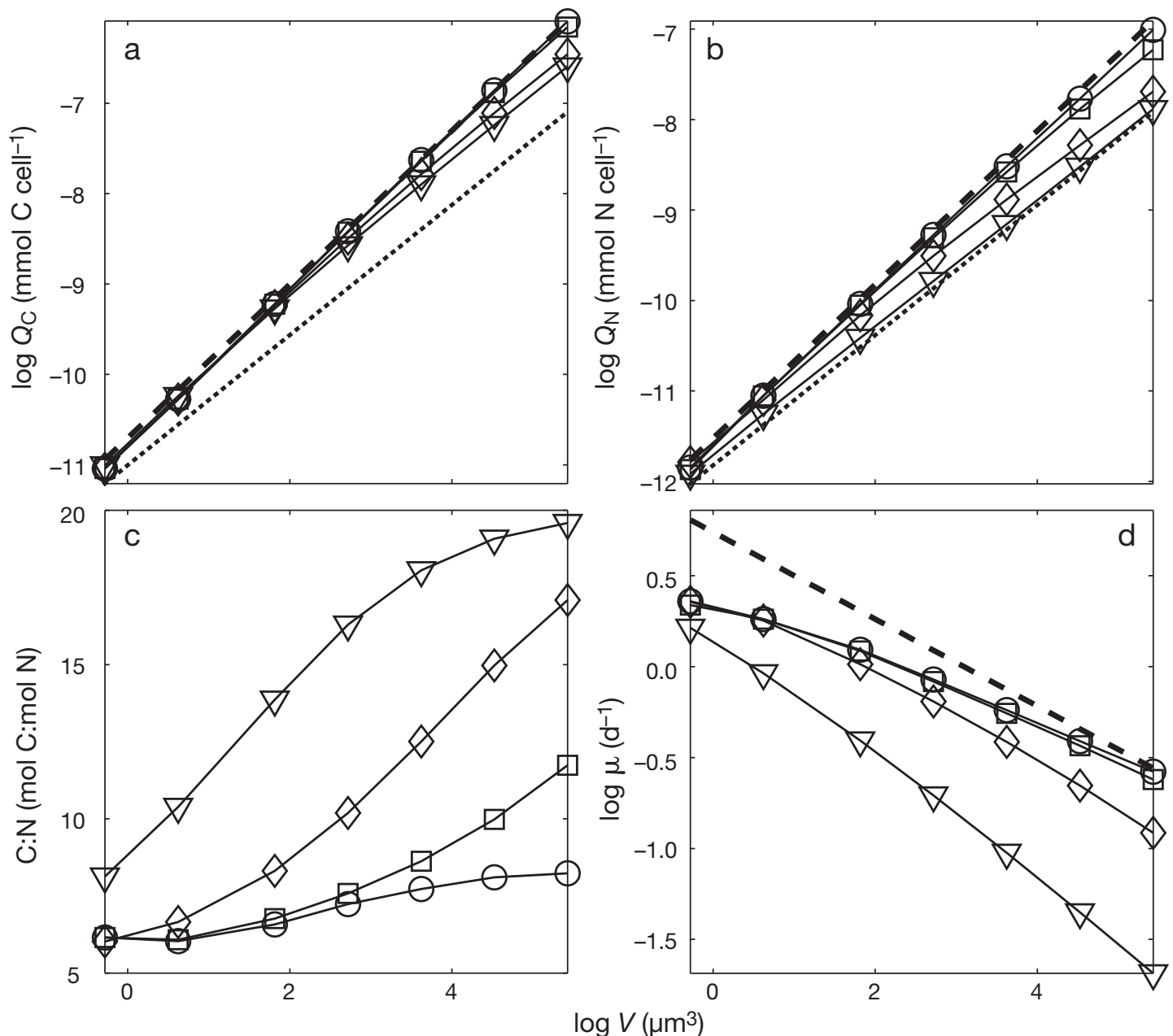

Fig. 3. Size-dependences of (a) $Q_{\mathrm{Cr}}$ (b) $Q_{\mathrm{N}}$ (c) C:N, and (d) $\mu$, under $\mathrm{NO}_{3}$ concentrations of $50(\mathrm{O}), 5$ ( $\square$ ), $0.5(\diamond)$, and $0.05 \mathrm{mmol} \mathrm{m}^{-3}$ $(\nabla)$. Irradiance is $320 \mu \mathrm{mol}$ photons $\mathrm{m}^{-2} \mathrm{~s}^{-1}$. Long-dashed lines on (a), (b) and (d) are $Q_{\mathrm{C}}^{\max }, Q_{\mathrm{N}}^{\max }$ and $\mu_{\infty}$, respectively. Shortdashed lines on (a) and (b) are $Q_{\mathrm{C}}^{\min }$ and $Q_{\mathrm{N}}^{\min }$, respectively. Abbreviations as in Fig. 1
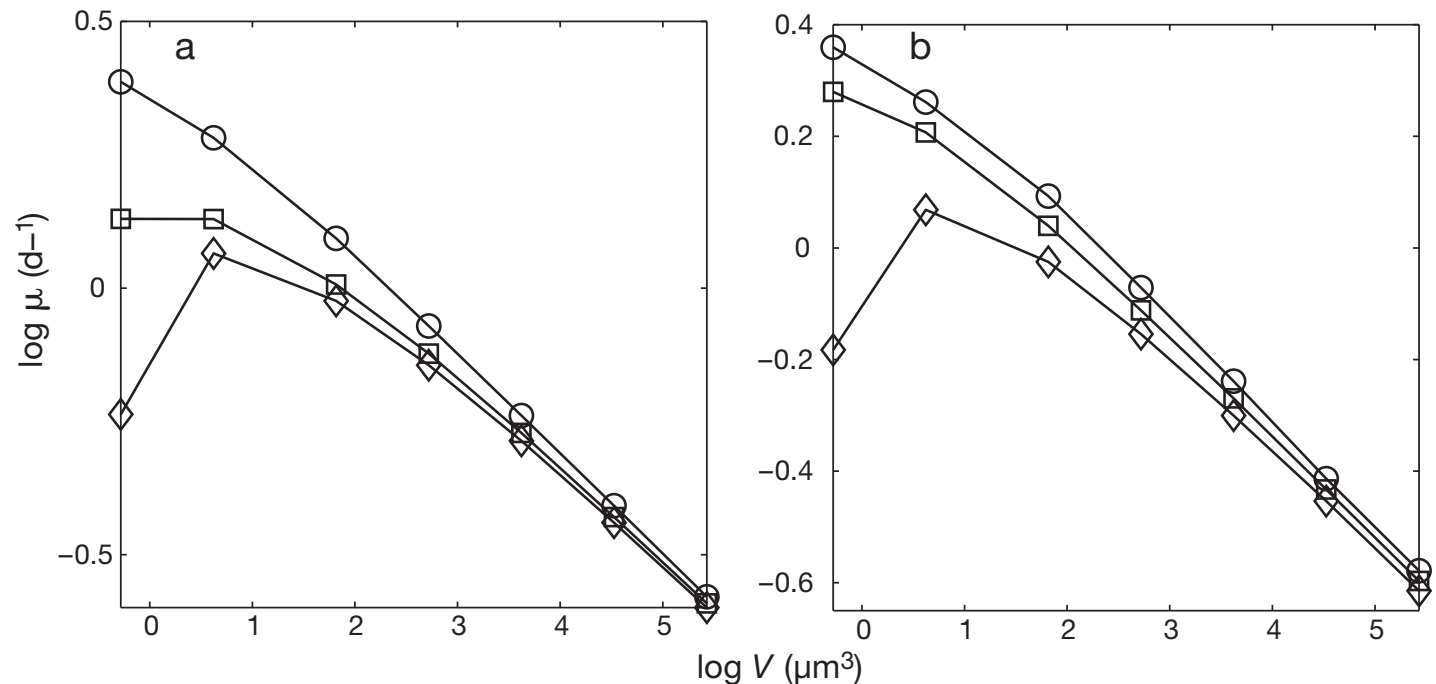

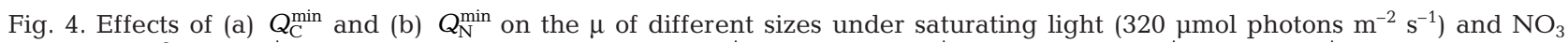
$\left(50 \mathrm{mmol} \mathrm{m}^{-3}\right)$. (a) $Q_{\mathrm{C}}^{\min }$ is increased from standard $6.6 \times Q_{\mathrm{N}}^{\min }(O)$, to $10 \times Q_{\mathrm{N}}^{\min }(\square)$, and $11 \times Q_{\mathrm{N}}^{\min }(\diamond)$. (b) $Q_{\mathrm{N}}^{\min }$ is increased from standard $1.5 \times 10^{-12}(\bigcirc)$ to $2.0 \times 10^{-12}(\square)$, and $2.5 \times 10^{-12} \mathrm{mmol} \mathrm{N}$ cell $^{-1}(\diamond)$. Abbreviations as in Fig. 1 
nent of $Q_{\min }$ increases the nutrient required for survival and cell integrity and reduces the nutrient storage capacity of cells $>1 \mu^{-3}$. As a result, the size-scaling exponent of $\mu_{\max }$ decreased, and that of $\mu_{\infty}$ increased (Fig. 5a). Under saturating light, cell quotas equilibrate towards $Q_{\max }$ the size-scaling exponent of $\mu_{\max }$ only slightly changes with that of $Q_{\min }$ (data not shown).

The sensitivity of the size-scaling exponent of $\mu$ to the size-scaling exponent of $Q_{\max }$ is tested under saturating light and nutrient, as $Q_{\mathrm{C}}$ and $Q_{\mathrm{N}}$ equilibrate towards $Q_{\text {max }}$. The sensitivity test is conducted by changing the size-scaling exponents of $Q_{\mathrm{C}}^{\max }$ and $Q_{\mathrm{N}}^{\max }$ simultaneously, assuming the $\mathrm{C}: \mathrm{N}$ ratio is not size dependent when cells are growing at saturating resources. The size-scaling exponent of $\mu$ is determined by that of $Q_{\max }$ under saturated light and nutrients. Increasing the size-scaling exponent of $Q_{\max }$ reduces the size-scaling exponents of both $\mu_{\infty}$ and $\mu_{\text {, }}$ as the size-scaling exponent of nutrient acquisition is not changed with that of $Q_{\max }$ (Fig. 5b).
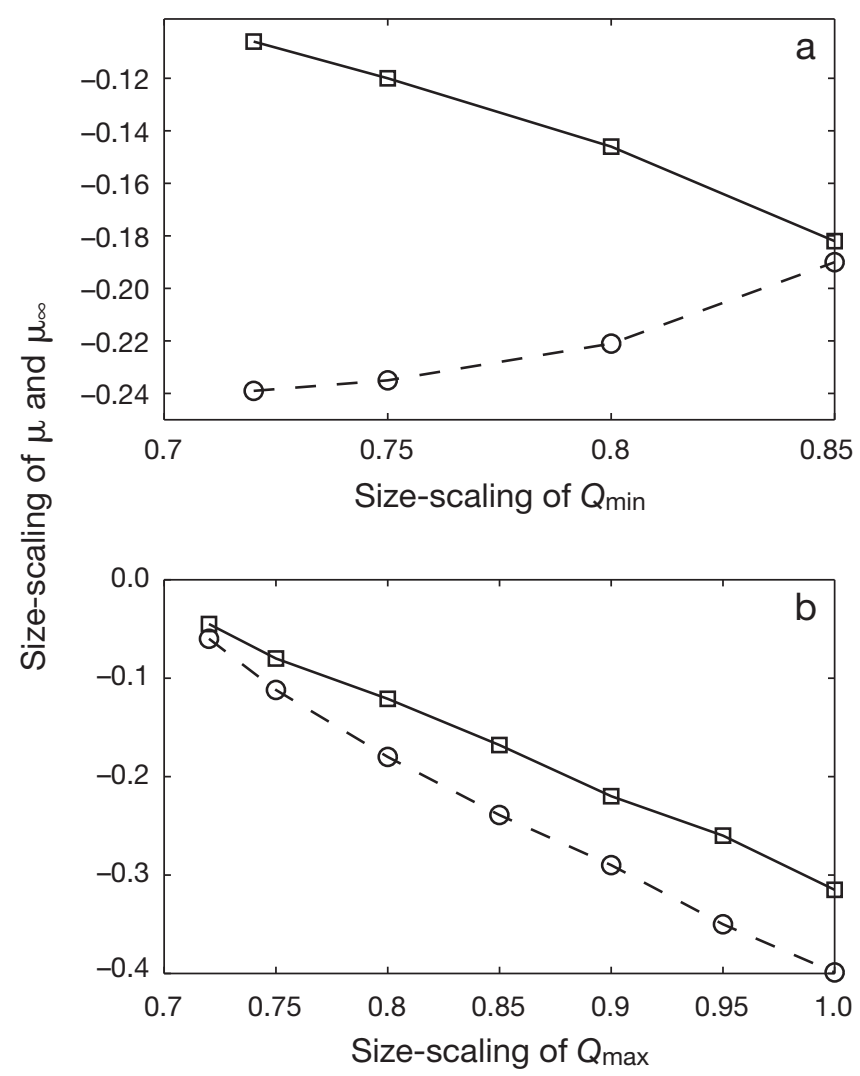

Fig. 5. Effects of the size-scaling exponents of (a) the minimum quota $\left(Q_{\min }\right)$ on those of the growth rate $(\mu$, solid line with $\square)$ and the infinity growth rate $\left(\mu_{\infty}\right.$, dashed line with $\left.O\right)$, under limiting light of $10 \mu \mathrm{mol}$ photons $\mathrm{m}^{-2} \mathrm{~s}^{-1}$ and saturating $\mathrm{NO}_{3}$ of $50 \mathrm{mmol} \mathrm{m}^{-3}$; and (b) the maximum quota $\left(Q_{\max }\right)$ on those of $\mu$ (solid line with $\square$ ) and $\mu_{\infty}$ (dashed line with $O$ ), under saturated light of $320 \mu \mathrm{mol}$ photons $\mathrm{m}^{-2} \mathrm{~s}^{-1}$ and $\mathrm{NO}_{3}$ of $50 \mathrm{mmol} \mathrm{m}^{-3}$

\section{Batch culture simulation}

When the phytoplankton are cultured under low light $\left(100 \mu \mathrm{mol}\right.$ photons $\left.\mathrm{m}^{-2} \mathrm{~s}^{-1}\right)$ but high $\mathrm{NO}_{3}, \mathrm{NO}_{3}$ remains saturated before PAR becomes limiting (Fig.6 $a, b)$. With decreasing light due to attenuation by phytoplankton biomass, $\mu$ of all size-classes decreases. During transition, $\mu$ of smaller cells decreases more than larger cells. When approaching steady state, $\mu$ of larger cells decreases, and is lower than smaller cells.

When the phytoplankton are cultured under high light, but low initial $\mathrm{NO}_{3}, \mathrm{NO}_{3}$ is depleted before PAR is further decreased to light limitation (Fig. 6c,d). $\mu$ of phytoplankton decreases with decreasing $\mathrm{NO}_{3}$ for all size-classes. Similar to Fig. $6 a$, b, the $\mu$ of smaller phytoplankton decreases more than that of larger cells during transition. When approaching steady state, $\mu$ decreases with increasing cell size. Compared to lightlimited culture (Fig. 6a,b), under $\mathrm{NO}_{3}$-limited culture, $\mu$ decreases more with increasing cell size when approaching steady state.

\section{DISCUSSION}

We used Droop's quota-dependent phytoplankton growth model to predict size scaling of phytoplankton growth in order to understand how resource acquisition, nutrient storage and the resource transportation network regulate the size scaling of phytoplankton growth under various light and nutrient conditions. Embedding the size-dependent bio-physical processes (including light-harvesting, photosynthesis and nutrient uptake) into a quota-dependent phytoplankton growth model allows size scaling of phytoplankton growth to emerge at various light and nutrient conditions of the ocean.

The size-scaling exponent of $\mu_{\max }(-0.17)$ obtained based on the empirical allometric relationships for resource acquisition and cellular nutrient contents (Table 1) is higher than $-1 / 4$, but agrees with the sizescaling exponents of $\mu_{\max }$ for phytoplankton reported in the literature (Banse 1976, Blasco et al. 1982, Tang 1995). The size-dependent difference between $\mu_{\max }$ and $\mu_{\infty}$ is attributed to the fact that the proportion $Q_{\min }: Q_{\max }$ increases with decreasing cell size. That is, for smaller cells, only a relatively small amount of stored nutrient is available for synthesizing essential cell materials, such as genetic materials in the genome and cell membranes $\left(Q_{\min }\right)$, which do not decrease indefinitely with cell size (Raven 1994). Those nonscalable materials occupy a relatively large percentage of cell space in small cells and prevent their $\mu$ from increasing to the potential maximum growth rate determined by cell size (Raven 1994). If $\mu_{\infty}$ is deter- 

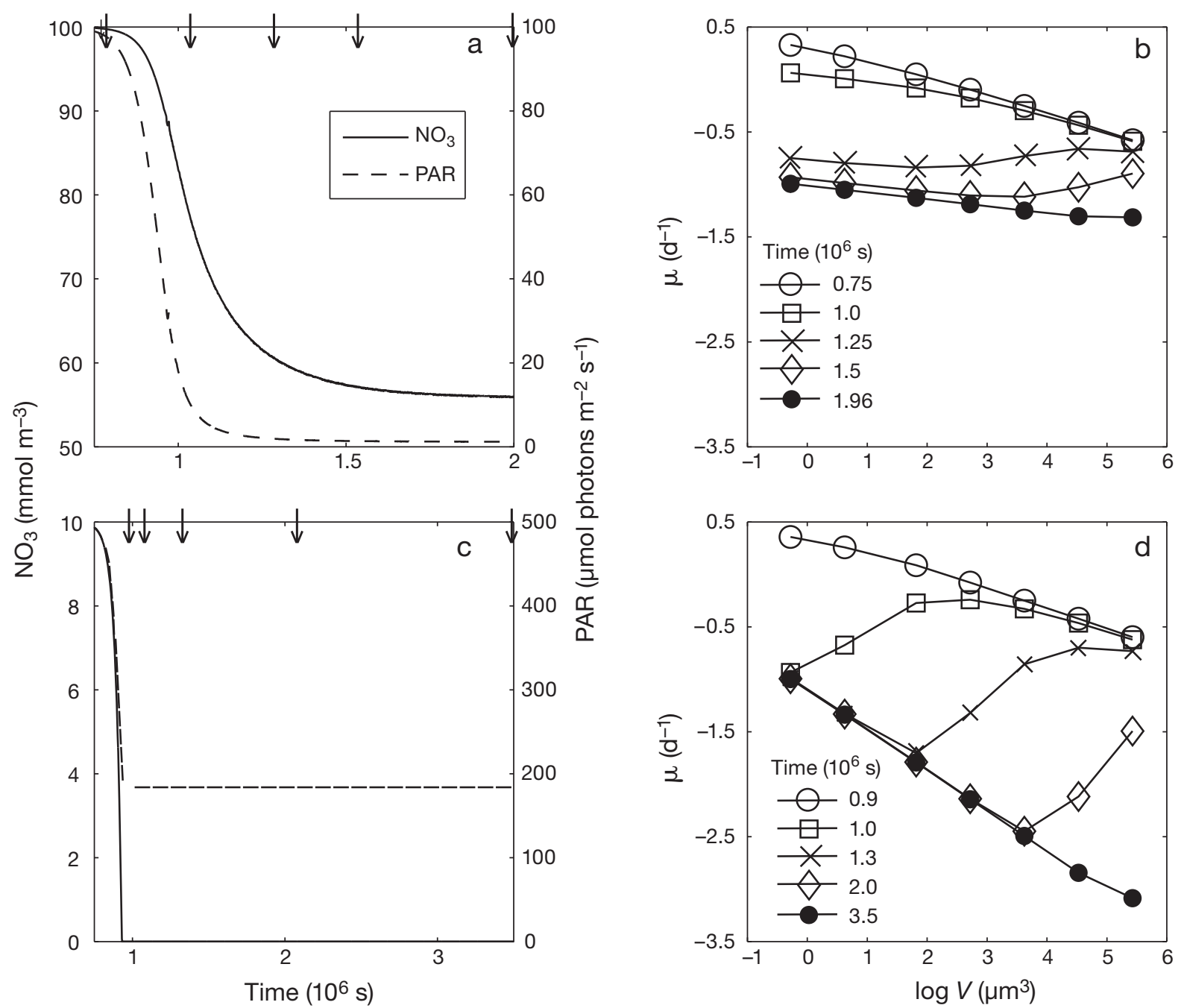

Fig. 6. Dynamics of $\mathrm{NO}_{3}$ and photosynthetically active readiation (PAR), and size-dependent growth rate $(\mu)$ of batch culture simulations. (a) $\mathrm{NO}_{3}$ and PAR during batch culture simulation at surface PAR of $100 \mu \mathrm{mol}$ photons m${ }^{-2} \mathrm{~s}^{-1}$ and initial $\mathrm{NO}_{3}$ of $100 \mathrm{mmol}$ $\mathrm{m}^{-3}$; arrows: time points (see b). (b) Size-dependent growth rates at the time points indicated as arrows on (a). (c) and (d) are similar to (a) and (b), respectively, but with surface PAR of $500 \mu \mathrm{mol}$ photons $\mathrm{m}^{-2} \mathrm{~s}^{-1}$, and an initial $\mathrm{NO}_{3}$ of $10 \mathrm{mmol} \mathrm{m}^{-3}$. $V$ : cell volume

mined by the resource transportation network, then the resource transport network of small cells may not be saturated by limited nutrient stored in the cells. Therefore, we hypothesize that $\mu_{\max }$ of small cells is limited by the nutrient storage capacity under saturated growth conditions. As the nutrient storage capacity increases with cell size, $\mu_{\max }$ gets closer to the $\mu_{\infty}$ set by the resource transportation network. Therefore, the size-scaling exponent of $\mu_{\max }(-0.17)$ is higher than that of $\mu_{\infty}(-0.24)$.

The $-1 / 4$ power law of the mass-specific metabolic rate at saturated resources is based on the fractal structure of the resource transportation network of multicullar plants and mammals (West et al. 1997, Brown et al. 2004, West \& Brown 2005). There is an ongoing debate over whether the resource transportation network obeys the rule of fractal structure or Euclidean structure (West et al. 1997, Dodds et al. 2001, West \& Brown 2005). The former suggests the $-1 / 4$ power size scaling, and the latter the $-\frac{1}{3}$ power size scaling. The size-scaling exponent of $\mu_{\infty}$ in the present study is close to $-1 / 4$. However, that is not sufficient to prove that the resource transportation network in phytoplankton also has fractal structure, since the size-scaling exponent of $\mu_{\infty}$ varies with the size-scaling exponents of $Q_{\max }$ and $Q_{\min }$ (Fig. 5). The size-scaling exponent of the transportation network may vary among different phylogenic groups of phytoplankton at the cellular level. For example, the size-scaling exponent of $Q_{N}^{\max }$ for dinoflagellates is 0.85 (Menden-Deuer \& Lessard 2000), and for diatoms it ranges from 0.81 (Montagnes \& Franklin 2001) to 0.87 (Blasco et al. 1982). Hence, the size- 
scaling exponent of $\mu_{\infty}$ or the transportation network may differ between the 2 groups of phytoplankton. There may be other factors contributing to the variations in size scaling of the resource transportation network that need to be considered (West \& Brown 2005).

With a Monod-type model, it is predicted that the size-scaling exponent of $\mu$ decreased from -0.25 to -0.33 when light decreased from saturated to a limiting level (Mei et al. 2009; their Figs. 3a \& 6a). The present model takes into account the fact that cell-specific nutrient quotas decrease with increasing cell size and nutrient quota changes with light and nutrient conditions. Consequently, contrasting responses of size scaling of $\mu$ to decreasing light is predicted. This result agrees with the observations of Schlesinger et al. (1981), who showed that growth rate was less size dependent under limiting light than under saturated light. The authors attributed this to cell-specific respiration, which decreases with increasing cell size. Under low light, the proportion of respiration in gross photosynthesis decreases with increasing size. Therefore, smaller cells do not have a growth advantage over larger cells under limiting light (Laws 1975, Banse 1976). It is possible that size-dependent respiration may contribute to the reduced growth advantage of smaller cells over larger cells under limiting light. However, for simplification, we did not consider respiration, except for respiration associated with $\mathrm{NO}_{3}$ assimilation in our model. Even when respiration associated with $\mathrm{NO}_{3}$ assimilation was set to 0 in Eq. (4), growth rate was still less size dependent under limiting light than under saturated light (data not shown).

Our model reveals that under limiting light, the sizescaling exponent of $Q_{\mathrm{C}}^{*}$ is slightly higher than that of $Q_{\mathrm{C}}^{\min }$ (Fig. 1a). That is, the $P_{\mathrm{C}}$ of larger cells produce more extra carbon beyond the essential structural materials than smaller cells, since the volume-specific amount of essential materials $\left(Q_{\min }\right)$ decreases with increasing cell size. Therefore, the growth advantage of smaller cells over larger cells decreases with decreasing light. This supports the prediction of Raven (1994) that small cells do not have a growth advantage over larger cells under limiting light because a relatively larger fraction of the cell volume of small cells is taken up by structural materials, and they, therefore, have less space than larger cells to store the photosynthetic machinery needed to increase photosynthesis. For the same reason, when the size-scaling exponent of $Q_{\min }$ is increased, that is, the cell-specific structural materials are increased and nutrient storage capacity is decreased for cells $>1 \mu^{3}$, then the size-scaling exponent of $\mu$ decreases (Fig. 5a). In other words, small cells have an advantage over larger cells under low light if the $Q_{\min }$ and nutrient storage capacity is not size dependent. This is the same prediction as in the
Monod model (Mei et al. 2009). Therefore, the Monodtype model is a special case of a quota-dependent growth model under limiting light.

Alternatively, under saturated light and $\mathrm{NO}_{3}$, increasing $Q_{\min }$ by a constant factor without changing the size-scaling exponent of $Q_{\min }$ for all size-classes decreases the nutrient storage capacity of cells of all size classes. This decreases $\mu_{\max }$ of small cells more than that of larger cells, and shifts the highest $\mu_{\max }$ to cells of $2 \mu \mathrm{m}$ diameter, instead of the smallest cells (Fig. 4). This pattern of size-dependent growth has been frequently observed (Chisholm 1992, Raven 1994, Bec et al. 2008). Therefore, our model shows that a size-dependent nutrient storage capacity can simulate such a pattern of a size-dependent maximum growth rate, without prescribing an ad hoc size-dependent maximum growth rate as in other works (e.g. Jiang et al. 2005) if a realistic $Q_{\min }$ is defined.

In contrast to light limitation, our model predicts that the size-scaling exponent of $\mu$ decreases with nutrient, or small cells have an advantage over larger cells under nutrient limitation when light is not limiting. The size-scaling exponent of $P_{\mathrm{C}}$ is higher than $Q_{\mathrm{C}}^{\mathrm{min}}$ under limiting light, but the size-scaling exponent of $P_{\mathrm{N}}$ is lower than that for $Q_{\mathrm{N}}^{*}$, which is close to that of the structural materials $\left(Q_{\mathrm{N}}^{\min }\right)$, under limiting nutrient (Fig. 3b). That is, the nutrient acquisition relative to the demand for structural materials is increasingly limiting with increasing cell size under limiting nutrient conditions. Thus, the extent of nutrient limitation increases with cell size, and the size-scaling exponent of $\mu$ decreases with nutrient concentration. Therefore, not only does the resource limitation change the size-scaling exponent of phytoplankton growth from the sizescaling exponent set by the resource transportation network (Finkel et al. 2004, Mei et al. 2009), but the size-dependent volume-specific structural materials, the nutrient storage capacity, and the limitations set by different resources (light or nutrients) also have different effects on the size-scaling exponent of $\mu$. In the future, the model should be extended to other important elements, such as phosphorus. Phosphorus limitation has important consequences for cell division (Müller et al. 2008), and thus may have different effects on the size scaling of phytoplankton growth.

Our model predicts the changes in phytoplankton size structure over vertical light and nutrient gradients in a typical stratified water column, or over an inshoreoffshore horizontal gradient. At the surface, phytoplankton are light saturated but nutrient limited and will be dominated by small cells, but farther down the water column, nutrient concentration increases while light becomes limiting. Phytoplankton growth will be less size dependent, and larger cells will less likely be outcompeted, or it should take longer for small cells to 
outcompete larger cells under light-limited conditions, favouring the coexistence of large and small cells in the water column, if grazing, advection and sinking are excluded. In a mesocosom experiment, Daufresne et al. (2009) observed that the size dependence of the phytoplankton biomass decreased with the light level of the water column. Similarly, across a horizontal trophic gradient, the size-biomass spectrum would be less steep in a coastal, eutrophic ocean than in offshore, oligotrophic oceans (Li 2002, Irwin et al. 2006).

Under dynamic conditions, the size-dependent responses of $\mu$ to light and nutrient supply could be more complicated than in the steady state, as illustrated in Fig. 6. With the depletion of nutrients and light with time, the $\mu$ of small cells decreases immediately, while the decrease in $\mu$ for larger cells is delayed because of the utilization of nutrient stored in the cells. This explains why large cells may not be outcompeted by small cells when nutrients are periodically supplied, and phytoplankton blooms of large cells are observed in nutrient-rich upwelling regions (Grover 1991, Irwin et al. 2006).

The C:N ratio of phytoplankton varies with the phylogenic groups and growth conditions, as the proportions of the various cellular components with different $\mathrm{C}: \mathrm{N}$, such as the resource acquisition machinery, growth machinery, and genetic materials, vary with taxonomic groups and growth conditions (Geider \& LaRoche 2002). The present study shows that under given growth conditions, C:N also varies with cell size. Goldman et al. (1979) and Goldman (1986) showed that the Redfield ratio could only be obtained when nutrient was not limiting relative to a given irradiance level. Our model results agree with their observations (Fig. 1). The differences in the size-dependent $C: N$ variation between limiting light and limiting nutrient conditions are related to the differences between the size scaling of $P_{\mathrm{C}}$ and $\rho_{\mathrm{N}}$ under limiting light and nutrient conditions, respectively. The size-scaling exponent of $P_{\mathrm{C}}$ under light limitation is higher than that of $\rho_{\mathrm{N}}$ under $\mathrm{NO}_{3}$ limitation. Therefore, under light limitation, C:N is less size dependent, while under $\mathrm{NO}_{3}$ limitation, $\mathrm{C}: \mathrm{N}$ increases with cell size (Fig. 3). If future climate change scenarios select for smaller cells due to increased stratification, and reduced nutrient supply (Daufresne et al. 2009, Finkel et al. 2010), the C:N of the phytoplankton community will increase, and the extent of the increase will be determined by the size structure of the phytoplankton community. C:N of phytoplankton biomass has been suggested to affect assimilation efficiency of zooplankton grazers (Jones et al. 2002, Jones \& Flynn 2005), and thus export through fast-sinking zooplankton fecal pellets. Therefore, phytoplankton size structure, along with their sizedependent C:N ratio, affects trophic interaction between autotrophs and heterotrophs and export of organic carbon.

By integrating the size-dependent resource acquisition and metabolism with ecological stoichiometry, we could better predict the elemental stoichiometry of the phytoplankton community, nutrient cycling and export to the ocean interior, based on phytoplankton size structure (see Allen \& Gillooly 2009, for example). This model embeds size-scaled resource acquisition, nutrient storage capacity, resource transportation network, and feedback between $\mathrm{C}$ and $\mathrm{N}$ metabolism into Droop's quota-dependent phytoplankton growth model, connecting the size-scaled growth to the stoichiometry of the phytoplankton community under various growth conditions. The model can be further extended to include other nutrients, such as phosphorus and trace metals, to predict the phytoplankton size structure, sizedependent elemental stoichiometry of those nutrients, and nutrient cycling in various environmental conditions.

As the size-dependent growth model presented here is able to simulate realistic size-dependent growth and variable $\mathrm{C}: \mathrm{N}$ stoichiometry under a large range of nutrient and light conditions, this model can be coupled with Ocean General Circulation Models to predict the size structure of the phytoplankton community and C and $\mathrm{N}$ cycling of the global ocean forced with realistic ocean physics, after some parameters are tuned (e.g. Baird \& Suthers 2007). The advantage of such a coupled model is that it can simulate many groups of phytoplankton over a large size range with few parameters that can be constrained by known size-scaling rules of physiological rates and some taxon-specific intercept of the allometric relationships (Thingstad et al. 2005). For such models to simulate a realistic size structure of the phytoplankton community in the ocean, we need more data on some critical parameters, such as the $Q_{\min }$ and $Q_{\max }$ of C and $\mathrm{N}$, in order to reduce the model uncertainty. Sensitivity tests show that those parameters are critically important in determining the size-scaling exponent of phytoplankton growth, and thus the size structure in the ocean (Fig. 5).

\section{CONCLUSIONS}

We simulated the effects of light and nutrients on the size scaling of phytoplankton growth using a quotadependent phytoplankton growth model based on empirical size-dependent resource acquisition, nutrient storage capacity, and the resource transportation network. The simulated size scaling of phytoplankton growth under light and nutrient limitation is consistent with field and lab observations. Though there is uncertainty with some empirical size-scaling parameters, 
such as $Q_{\min }$ and $Q_{\max }$ the success of the model suggests that resource acquisition and nutrient storage capacity are the main factors determining the size scaling of growth under various light and nutrient conditions. The deviation of the size-scaling exponent of $\mu_{\max }$ from the universal exponent of $-1 / 4$ is due to the size-dependent nutrient storage capacity relative to the essential structural materials required to sustain their survival, with small cells being more limited by nutrient storage than larger cells.

The variation in the $\mathrm{C}: \mathrm{N}$ ratio of the phytoplankton community is not only determined by growth conditions, such as the availability of light and nutrients, but also by cell size. The size-dependence of C:N differs between light limitation and nutrient limitation and is caused by the differences in the size-scaling exponent between $P_{\mathrm{C}}$ and $\rho_{\mathrm{N}}$, relative to the size scaling of the minimum quota of $\mathrm{C}$ and $\mathrm{N}$, respectively. There is a strong connection between changes in the size structure of the phytoplankton community and the C:N stoichiometry of phytoplankton biomass, and hence, carbon and nitrogen cycles in marine ecosystems may be changed by phytoplankton size structure in response to future climate change.

Acknowledgements. This research was supported by the National Science and Engineering Council (NSERC) of Canada, New Brunswick Innovation Fund (NBIF), and Atlantic Computational Excellence Network (ACENET). The comments of the 2 anonymous reviewers and G. Savidge were critical in improving the earlier version of the manuscript.

\section{LITERATURE CITED}

Agustí S (1991) Allometric scaling of light absorption and scattering by phytoplankton cells. Can J Fish Aquat Sci 48:763-767

Aksnes DL, Egge JK (1991) A theoretical model for nutrient uptake in phytoplankton. Mar Ecol Prog Ser 70:65-72

> Allen AP, Gillooly JF (2009) Towards an integration of ecological stoichiometry and the metabolic theory of ecology to better understand nutrient cycling. Ecol Lett 12:369-384

Baird ME, Suthers IM (2007) A size-resolved pelagic ecosystem model. Ecol Model 203:185-203

Banse K (1976) Rates of growth, respiration and photosynthesis of unicellular algae as related to algal size. J Phycol 12: 135-140

> Banse K (1982) Cell volumes, maximum growth rates of unicellular algae and ciliates, and the role of ciliates in the marine pelagial. Limnol Oceanogr 27:1059-1071

$>$ Bec B, Collos Y, Vaquer A, Mouillot D, Souchu P (2008) Growth rate peaks at intermediate cell size in marine photosynthetic picoeukaryotes. Limnol Oceanogr 53:863-867

Behrenfeld MJ, Marañón E, Siegel DA, Hooker SB (2002) Photoacclimation and nutrient-based model of light-saturated photosynthesis for quantifying oceanic primary production. Mar Ecol Prog Ser 228:103-117

Blasco D, Packard TT, Garfield PC (1982) Size dependence of growth rate, respiratory electron transport system activity, and chemical composition in marine diatoms in the laboratory. J Phycol 18:58-63

Brown JH, Gillooly JF, Allen AP, Savage VM, West GB (2004) Toward a metabolic theory of ecology. Ecology 85: 1771-1789

Chisholm SW (1992) Phytoplankton size. In: Falkowski PG, Woodhead AR (eds) Primary productivity and biogeochemical cycles in the sea. Plenum Press, New York, NY, p 213-237

Daufresne M, Lengfellner K, Sommer U (2009) Global warming benefits the small in aquatic ecosystems. Proc Natl Acad Sci USA 106:12788-12793

Dodds PS, Rothman DH, Weitz JS (2001) Reexamination of the '3/4 laws' of metabolism. J Theor Biol 209:9-27

Droop MR (1968) Vitamin B and marine ecology. IV. The kinetics of uptake, growth and inhibition in Monochrysis lutheri. J Mar Biol Assoc UK 48:689-733

Droop MR (1973) Some thoughts on nutrient limitation in algae. J Phycol 9:264-272

Falkowski PG (2000) Rationalizing elemental ratios in unicellular algae. J Phycol 36:3-6

Falkowski PG, Raven JA (2007) Aquatic photosynthesis, 2nd edn. Princeton University Press, Princeton, NJ

Finkel ZV (2001) Light absorption and size scaling of lightlimited metabolism in marine diatoms. Limnol Oceanogr 46:86-94

Finkel ZV (2007) Does phytoplankton cell size matter? The evolution of modern marine food webs. In: Falkowski PG, Knoll AH (eds) The evolution of aquatic photoautotrophs. Elsevier, Amsterdam, p 333-350

> Finkel ZV, Irwin AJ (2000) Modeling size-dependent photosynthesis: light absorption and the allometric rule. J Theor Biol 204:361-369

> Finkel ZV, Irwin AJ, Schofield O (2004) Resource limitation alters the 3/4 size scaling of metabolic rates in phytoplankton. Mar Ecol Prog Ser 273:269-279

Finkel ZV, Katz ME, Wright JD, Schofield OME, Falkowski PG (2005) Climatically driven macroevolutionary patterns in the size of marine diatoms over the Cenozoic. Proc Natl Acad Sci USA 102:8927-8932

> Finkel ZV, Sebbo J, Feist-Burkhardt S, Irwin AJ and others (2007) A universal driver of macroevolutionary change in the size of marine phytoplankton over the cenozoic. Proc Natl Acad Sci USA 104:20416-20420

- Finkel ZV, Beardall J, Flynn KJ, Quigg A, Alwyn T, Rees V, Raven JA (2010) Phytoplankton in a changing world: cell size and elemental stoichiometry. J Plankton Res 32: $119-137$

Flynn KJ (2008) Use, abuse, misconceptions and insights from quota models - the Droop cell quota model 40 years on. Oceanogr Mar Biol Annu Rev 46:1-23

> Fujiki T, Taguchi S (2002) Variability in chlorophyll a specific absorption coefficient in marine phytoplankton as a function of cell size and irradiance. J Plankton Res 24:859-874

- Geider RJ, LaRoche J (2002) Redfield revisited: variability of $\mathrm{C}: \mathrm{N}: \mathrm{P}$ in marine microalgae and its biochemical basis. Eur J Phycol 37:1-17

Geider RJ, Platt T, Raven JA (1986) Size dependence of growth and photosynthesis in diatoms: a synthesis. Mar Ecol Prog Ser 30:93-104

> Geider RJ, MacIntyre HL, Kana TM (1998) A dynamic regulatory model of phytoplanktonic acclimation to light, nutrients, and temperature. Limnol Oceanogr 43:679-694

> Goldman JC (1986) On phytoplankton growth rates and particulate C:N:P ratios at low light. Limnol Oceanogr 31:1358-1363

Goldman JC, MacCarthy JJ (1978) Steady state growth and 
ammonium uptake of a fast-growing marine diatom. Limnol Oceanogr 23:695-703

Goldman JC, McCarthy JJ, Peavey DG (1979) Growth rate influence on the chemical composition of phytoplankton in oceanic waters. Nature 279:210-215

Grover JP (1989) Influence of cell shape and size on algal competitive ability. J Phycol 25:402-405

Grover JP (1991) Resource competition in a variable environment: phytoplankton growing according to the variable internal-stores model. Am Nat 138:811-835

Hansen B, Bjørnsen PK, Hansen PJ (1994) The size ratio between planktonic predators and their prey. Limnol Oceanogr 39:395-403

Harrison WG, Harris LR, Irwin BD (1996) The kinetics of nitrogen utilization in the oceanic mixed layer: nitrate and ammonium interactions at nanomolar concentrations. Limnol Oceanogr 41:16-32

Hein M, Pedersen MF, Sand-Jensen K (1995) Size-dependent nitrogen uptake in micro- and macroalgae. Mar Ecol Prog Ser 118:247-253

Irwin AJ, Finkel ZV, Schofield OME, Falkowski PG (2006) Scaling-up from nutrient physiology to the size-structure of phytoplankton communities. J Plankton Res 28:459-471

Jiang L, Schofield OME, Falkowski PG (2005) Adaptive evolution of phytoplankton cell size. Am Nat 166:496-505

Jones RH, Flynn KJ (2005) Nutritional status and diet composition affect the value of diatoms as copepod prey. Science 307:1457-1459

> Jones RH, Flynn KJ, Anderson TR (2002) Effect of food quality on carbon and nitrogen growth efficiency in the copepod Acartia tonsa. Mar Ecol Prog Ser 235:147-156

Laws EA (1975) The importance of respiration losses in controlling the size distribution of marine phytoplankton. Ecology 56:419-426

Legendre L, Le Fevre J (1989) Hydrodynamical singularities as controls of recycled versus export production in oceans. In: Berger WHV, Smetacek S, Wefer G (eds) Productivity of the ocean: present and past. John Wiley \& Sons, New York, NY, p 49-63

Li WKW (2002) Macroecological patterns of phytoplankton in the northwestern North Atlantic Ocean. Nature 419: 154-157

Litchman E, Klausmeier CA (2008) Trait-based community ecology of phytoplankton. Annu Rev Ecol Evol Syst 39: 615-639

Litchman E, Klausmeier CA, Schofield OM, Falkowski PG (2007) The role of functional traits and trade-offs in structuring phytoplankton communities: scaling from cellular to ecosystem level. Ecol Lett 10:1170-1181

Mei ZP, Finkel ZV, Irwin AJ (2009) Light and nutrient availability affect the size-scaling of growth in phytoplankton. J Theor Biol 259:582-588

Menden-Deuer S, Lessard EJ (2000) Carbon to volume relationships for dinoflagellates, diatoms, and other protist plankton. Limnol Oceanogr 45:569-579

Montagnes DJS, Franklin DJ (2001) Effects of temperature on diatom volume, growth rate, and carbon and nitrogen content: reconsidering some paradigms. Limnol Oceanogr 46: 2008-2018

Montagnes DJS, Berges JA, Harrison PJ, Taylor FJR (1994) Estimating carbon, nitrogen, protein, and chlorohyll a from volume in marine phytoplankton. Limnol Oceanogr 39:1044-1060

Morel A, Bricaud A (1981) Theoretical results concerning light absorption in a discrete medium, and application to specific absorption of phytoplankton. Deep-Sea Res I 28A: 1375-1393

Editorial responsibility: Graham Savidge,

Portaferry, UK
Müller MN, Anitia AN, LaRoche J (2008) Influence of cell cycle phase on calcification in the coccolithophore Emiliania huxleyi. Limnol Oceanogr 53:506-512

Pasciak WJ, Gavis J (1974) Transport limitation of nutrient uptake in phytoplankton. Limnol Oceanogr 19:881-888

Raven JA (1984) A cost-benefit analysis of photon absorption by photosynthetic unicells. New Phytol 98:593-625

Raven JA (1994) Why are there no picoplanktonic $\mathrm{O}_{2}$ evolvers with volumes less than $10^{-19} \mathrm{~m}^{3}$ ? J Plankton Res 16:565580

Raven JA, Kubler JE (2002) New light on the scaling of metabolic rate with the size of algae. J Phycol 38:11-16

> Schlesinger DA, Molot LA, Shuter BJ (1981) Specific growth rates of freshwater algae in relation to cell size and light intensity. Can J Fish Aquat Sci 38:1052-1058

> Shuter BJ (1978) Size-dependence of phosphorus and nitrogen subsistence quota in unicullar microorganisms. Limnol Oceanogr 23:1248-1255

Smayda TJ (1970) The suspension and sinking of phytoplankton in the sea. Oceanogr Mar Biol Annu Rev 8:353-424

Sommer U (1989) Maximal growth rates of antarctic phytoplankton: only weak dependence on cell size. Limnol Oceanogr 34:1109-1112

Sterner RW, Elser JJ (2002) Ecological stoichiometry: the biological elements from molecules to the biosphere. Princeton University Press, Princeton, NJ

Sunda WG, Huntsman SA (1997) Interrelated influence of iron, light and cell size on marine phytoplankton growth. Nature 390:389-392

Sunda WG, Shertzer KW, Hardison DR (2009) Ammonium uptake and growth models in marine diatoms: Monod and Droop revisited. Mar Ecol Prog Ser 386:29-41

Tang EPY (1995) The allometry of algal growth rates. J Plankton Res 17:1325-1335

Tang EPY, Peters RH (1995) The allometry of algal respiration. J Plankton Res 17:303-315

Thingstad TF, Ovreas L, Egge JK, Lovdal T, Heldal M (2005) Use of non-limiting substrates to increase size; a generic strategy to simultaneously optimize uptake and minimize predation in pelagic osmotrophs? Ecol Lett 8:675-682

> Thompson PA, Harrison PJ, Parslow JS (1991) Influence of irradiance on cell volume and carbon quota for ten species of marine phytoplankton. J Phycol 27:351-360

Tozzi S, Schofield O, Falkowski P (2004) Historical climate change and ocean turbulence as selective agents for two key phytoplankton functional groups. Mar Ecol Prog Ser 274:123-132

> Verdy A, Follows M, Flierl G (2009) Optimal phytoplankton cell size in an allometric model. Mar Ecol Prog Ser 379: $1-12$

Verity PG, Robertson CY, Tronzo CR, Andrews MG, Nelson JR, Sieracki ME (1992) Relationships between cell volume and the carbon and nitrogen content of marine photosynthetic nanoplankton. Limnol Oceanogr 37:1434-1446

> Waite A, Fisher A, Thompson PA, Harrison PJ (1997) Sinking rate versus cell volume relationships illuminate sinking rate control mechanisms in marine diatoms. Mar Ecol Prog Ser 157:97-108

- Weitz JS, Levin SA (2006) Size and scaling of predator-prey dynamics. Ecol Lett 9:548-557

- West GB, Brown JH (2005) The origin of allometric scaling laws in biology from genomes to ecosystems: towards a quantitative unifying theory of biological structure and organization. J Exp Biol 208:1575-1592

West GB, Brown JH, Enquist BJ (1997) A general model for the origin of allometric scaling laws in biology. Science 276:122-126

Submitted: October 18, 2010; Accepted: March 27, 2011

Proofs received from author(s): July 22, 2011 